\title{
Evaluation of Technical
}

Assistance to Post-Conflict

Countries-Mozambique and

Rwanda 


\section{Evaluation of Technical Assistance to Post-Conflict Countries: MOZAMBIQUe AND RWANDA}

Prepared by the Statistics Department

Approved by Adelheid Burgi-Schmelz

February 18, 2009

Contents Page

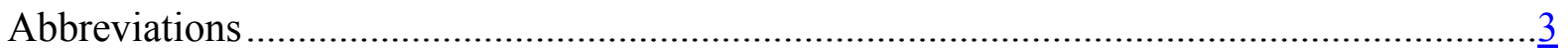

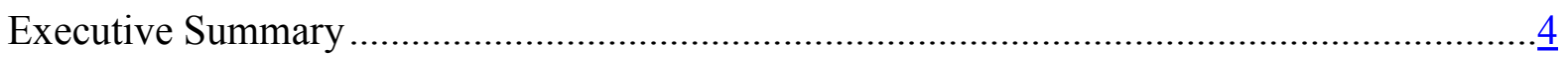

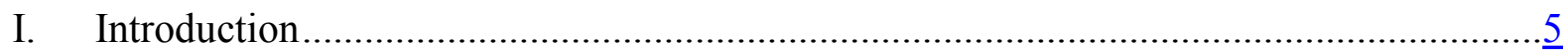

II. Summary of Findings in Mozambique and Rwanda................................................

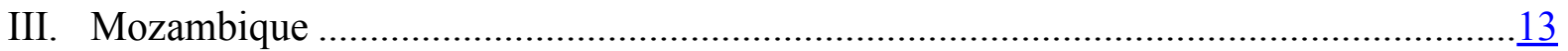

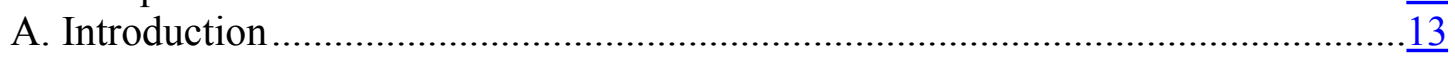

B. Inputs of the Program ............................................................................

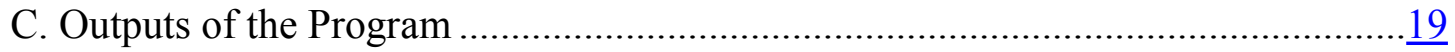

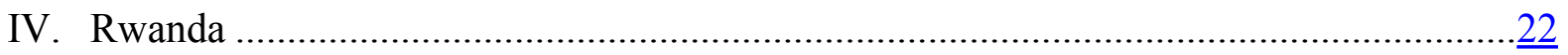

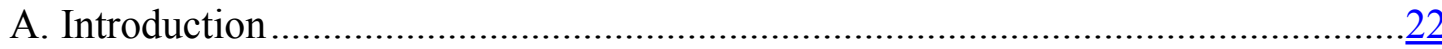

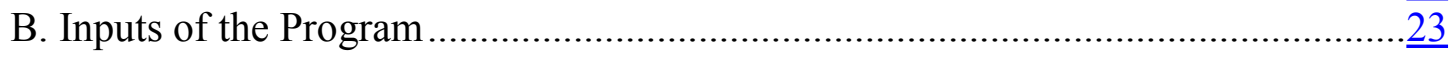

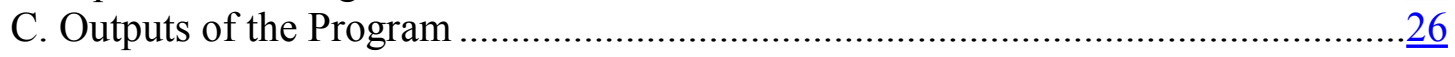

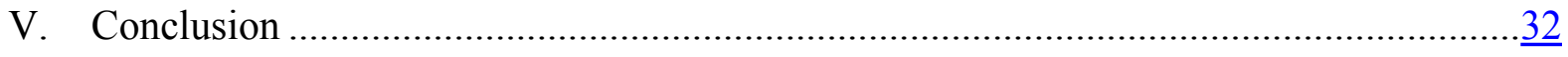

Text Table

1. STA Technical Assistance (TA) to Mozambique and Rwanda, 2000-08 .......................

Boxes

1. Mozambique and Rwanda: Political and Economic Settings ...................................... $\underline{8}$

2. STA's Technical Assistance Evaluation Missions to Mozambique and Rwanda:

Assessment, Risks, and Priorities Going Forward ...................................................

3. Mozambique's Technical Assistance Coordinator and the Role of the IMF ..................15 


\section{Appendix Tables}

1. Mozambique: TA Missions Delivered by STA During 2000-08 $\underline{34}$

2. Mozambique: Participants in IMF Training Courses During 2003-08 ......................... $\underline{35}$

3. Mozambique: Authorities' Views on STA's Technical Assistance

4. Mozambique: Overview of Current Practices Regarding Coverage, Periodicity, and Timeliness of Data Compared with the GDDS

5. Rwanda: STA, East AFRITAC, and DFID TA Missions Delivered

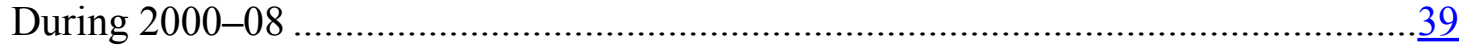

6. Rwanda: Participants in IMF Training Courses During 2000-08 ...............................40

7. Rwanda: Authorities' Views on STA's Technical Assistance ..................................... 41

8. Rwanda: Overview of Current Practices Regarding Coverage, Periodicity, and Timeliness of Data Compared with the GDDS. 


\section{AbBreviations}

\begin{tabular}{|c|c|}
\hline AFR & African Department, IMF \\
\hline AfDB & African Development Bank \\
\hline AFRITAC & Africa Regional Technical Assistance Center \\
\hline BoM & Bank of Mozambique \\
\hline $\mathrm{BoP}$ & Bank of Portugal \\
\hline $\mathrm{BOP}$ & Balance of payments \\
\hline CPI & Consumer price index \\
\hline DANIDA & Danish International Development Agency \\
\hline DFID & Department for International Development (U.K.) \\
\hline DSBB & Dissemination Standards Bulletin Board \\
\hline DS & Direction Statistique, Rwanda \\
\hline FAD & Fiscal Affairs Department, IMF \\
\hline GDDS & General Data Dissemination System \\
\hline EDPRS & Economic Development and Poverty Reduction Strategy, Rwanda \\
\hline GFS & Government finance statistics \\
\hline ICS & Integrated correspondence system \\
\hline IMD & Integrated monetary database \\
\hline INE & Instituto Nacional de Estatistica, Mozambique \\
\hline INS & IMF Institute \\
\hline JSA & Japan Administered Account for Selected Fund Activities \\
\hline MDGs & Millennium Development Goals \\
\hline MFS & Monetary and financial statistics \\
\hline MINECOFIN & Ministry of Finance and Economic Planning, Rwanda \\
\hline $\mathrm{MoF}$ & Ministry of Finance, Mozambique \\
\hline MTEF & Medium-term expenditure framework \\
\hline NA & National accounts \\
\hline NBR & National Bank of Rwanda \\
\hline NDS & National Directorate of Statistics, Mozambique \\
\hline NISR & National Institute of Statistics of Rwanda \\
\hline NSDP & National summary data page \\
\hline NSDS & National Strategy for the Development of Statistics, Rwanda \\
\hline NSO & National statistical organization \\
\hline NSS & National statistical system \\
\hline PFM & Public finance management \\
\hline PPI & Producer price index \\
\hline PRSP & Poverty reduction strategy paper \\
\hline ROSC & Report on the Observance of Standards and Codes \\
\hline RRA & Rwanda Revenue Authority \\
\hline SECO & Swiss State Secretariat for Economic Affairs \\
\hline$S N A$ & System of National Accounts \\
\hline SRFs & Standardized report forms \\
\hline STA & Statistics Department, IMF \\
\hline TA & Technical assistance \\
\hline TACSN & Technical assistance country strategy note \\
\hline TCAP & Technical Cooperation Action Plan \\
\hline UNDP & United Nations Development Programme \\
\hline
\end{tabular}




\section{EXECUTIVE SUMMARY}

This evaluation of technical assistance (TA) in statistics covers two post-conflict countries, namely, Mozambique and Rwanda during the period 2000-08. The TA, including training, covered the broad spectrum of the Statistics Department's (STA) program, including collaboration with the East Africa Regional Technical Assistance Center (East AFRITAC), the U. K. Department for International Development (DFID), and the Japanesefunded General Data Dissemination System (GDDS) projects, as well as TA funded directly from the IMF's budget. The emerging lessons also provide a useful guide to future TA to nonEnglish-speaking countries.

The evaluation is based on missions to each country and relied on responses to questionnaires, desk reviews of available data, and discussions with country authorities, donors, data users, and national officials who participated in IMF courses in statistics.

Both Mozambique and Rwanda were initially slow to absorb TA as they rebuilt their institutions following severe conflicts. New legal frameworks provided a basis to establish autonomous national statistical organizations (NSOs), which have enhanced awareness and mobilized resources to spearhead and sustain momentum for reforms.

The reform experience and the impact of $\mathrm{TA}$ in the various statistical areas differ significantly from Mozambique to Rwanda and even within each country. This reflects not only differences in the amount of TA delivery but also the legal and institutional legacies and resources available to the TA recipient statistical agencies.

Notwithstanding the gradual improvement in the effectiveness of TA and institutional statistical capacity, there is room for further progress. The key challenge is the availability of financial and human resources, particularly in NSOs and ministries of finance, to, among other things, generate the requisite source data to compile real sector and government finance statistics. Moreover, NSOs have had limited success in promoting national agency coordination and the GDDS framework to compile and disseminate data. Data users concur that more efforts are still needed to promote public access to high-quality and timely data. The central banks' greater access to resources has permitted better absorption and retention of TA in balance of payments and monetary and financial statistics.

The risks to further enhancement in the effectiveness of TA and its sustainability comprise mainly access to adequate medium-term resources. These risks would be minimized by integrating statistical activities into the countries' poverty reduction strategy papers, which provide an operational framework for establishing and funding overall reform priorities. Mozambique has made the most progress in this respect, while Rwanda still has some way to go.

The evaluation missions agreed with the authorities on priority areas to guide future TA. The review lessons remain important to enhancing future assistance to each country. 


\section{INTRODUCTION}

1. The evaluation of technical assistance (TA), including training, to member countries provides an opportunity for the TA providers and recipients to draw lessons that can inform efforts to enhance the effectiveness of TA programs. Indeed, following the recommendations of the IMF's Independent Evaluation Office in $2005,{ }^{1}$ such evaluations have become an increasingly integral component of IMF TA activities. TA evaluation helps to ascertain what works and does not, refine ongoing TA programs, and provide guidance for future TA programs. For countries that receive TA, the evaluation provides an opportunity to reflect on the objectives of the TA program, assess possible shortfalls, and determine what could be done to improve future implementation. With regard to TA in statistics (where the dissemination of the key output, namely, data to the public is critical to better decision making), evaluation missions also offer a chance to discuss with data users and help to enhance the dialogue with data compilers to promote better end products.

\section{Accordingly, the IMF's Statistics Department (STA) conducted two missions to} Mozambique and Rwanda to evaluate its TA programs in post-conflict countries in Africa over the period 2000-08. ${ }^{2}$ Both countries had previously suffered major economic and political dislocations - a prolonged civil war in Mozambique and a civil war and genocide in Rwanda - and received a sizable amount of TA to help rebuild the destroyed statistical capacity. In both cases, it took several years to create an environment that would permit basic IMF TA to begin to have some of its intended effects. Both countries are also non-English speaking and thus provided an opportunity to assess the additional challenges entailed in providing them TA.

3. The importance of overall IMF TA activities (including statistical topics) in Mozambique was highlighted by that country's participation in a pilot program involving the preparation of technical assistance country strategy notes (TACSNs) for 10 countries in the IMF during FY 2006-07. The country received a sizable amount of TA from STA in most statistical topical areas, including through the Lusophone Africa General Data Dissemination System (GDDS) Project, and since late 2006, the U.K. Department for International Development (DFID)-financed GDDS Project. In addition, STA conducted two data Report on the Observance of Standards and Codes (ROSC) missions in 2002 and 2005 to assess the overall quality of the macroeconomic statistical system and provided extensive

\footnotetext{
${ }^{1}$ See Summing Up by the Acting Chair on the Independent Evaluation Office-Evaluation of the Technical Assistance Provided by the Fund and Conclusions of the Task Force on IMF Technical Assistance.

${ }^{2}$ The missions to Mozambique (September 30-October 3, 2008) and Rwanda (September 1-5, 2008) included Candida Andrade and Theodore Bikoi, respectively, and were both led by Robin Kibuka. Both missions were ably assisted by the IMF resident representatives and their staffs.
} 
recommendations to improve it. The data ROSCs and Mozambique's participation in the GDDS projects provided a relatively more structured context to provide TA to the country. Moreover, 27 Mozambican officials benefited from training by attending a number of courses at the IMF Institute (INS) and those arranged by STA in collaboration with other organizations (Table 1 and Appendix Tables 1 and 2).

Table 1. STA Technical Assistance (TA) to Mozambique and Rwanda, 2000-08

\begin{tabular}{|c|c|c|c|c|c|c|c|c|c|c|}
\hline & FY 2000 & FY 2001 & FY 2002 & FY 2003 & FY 2004 & FY 2005 & FY2006 & FY 2007 & FY 2008 & Total \\
\hline \multicolumn{11}{|l|}{ TA Field time } \\
\hline AFR & 5.758 & 4.917 & 5.235 & 11.115 & 13.267 & 11.935 & 11.987 & 10.101 & 13.698 & 88.01 \\
\hline Mozambique & 0.088 & 0.274 & 0 & 0.844 & 1.014 & 1.132 & 1.038 & 0.413 & 0.168 & 4.97 \\
\hline Rwanda ${ }^{2 !}$ & 0 & 0.108 & 0 & 0.012 & 0.489 & 0 & 0.085 & 0.108 & 0.263 & 1.07 \\
\hline \multicolumn{11}{|l|}{ Training $^{3 /}$} \\
\hline Mozambique & 0 & 0 & 0 & 1 & 7 & 2 & 6 & 9 & 2 & 27 \\
\hline Rwanda $^{2}$ & 2 & 2 & 6 & 2 & 4 & 4 & 6 & 8 & 12 & 46 \\
\hline
\end{tabular}

Sources: TIMS; and course attendance records.

${ }^{1 /}$ In person years.

2/ Does not include East AFRITAC missions before 2004.

${ }^{3 /}$ Number of participants, calendar year.

4. A more coordinated TA program for Rwanda evolved from a multisector TA mission in 2003, which provided a comprehensive assessment of the statistical system and made recommendations for improvement, including Rwanda's participation in the GDDS. STA has provided several TA missions covering all the major topics in macroeconomics. In addition, since 2003, Rwanda has benefited from the assistance of a resident real sector statistics advisor, based in East AFRITAC, ${ }^{3}$ who conducted regular TA missions to the country. The TA program has been supplemented by a training mission in national accounts (NA) in 2006 and, since 2000, the training of a total of 46 Rwandese officials in INS and other STA courses and seminars in statistics (Appendix Tables 5 and 6).

5. This evaluation is based on the missions' findings and was also informed by a review of various relevant documents. The approach employed three broad types of instruments. First, a survey was conducted in advance at each of the TA recipient institutions using a standardized questionnaire to solicit views on various aspects of the STA TA program. Each survey was accompanied by a detailed matrix to report on the status of implementation of the action plans for the respective area. Second, a desk review was conducted to ascertain each country's data provision to STA and the information available at headquarters on the implementation of missions' recommendations in each topical area. Third, discussions were conducted with key representatives of the agencies receiving TA to

\footnotetext{
3 East AFRITAC was established by the IMF and several donors in September 2003 in Dar es Salaam, Tanzania to provide TA to six countries: Eritrea, Ethiopia, Kenya, Rwanda, Tanzania, and Uganda. Malawi was added to the list of recipient countries in 2007 . The center has one resident statistical advisor, among others.
} 
seek clarification on main issues arising from the survey responses and desk reviews, as well as to solicit views on key aspects of program design and implementation. Discussions were also undertaken with representatives of the business community, civil society groups, and academics. In addition, the missions met with donors who provide TA and resources in the statistics area. The objective of these meetings was to ascertain progress with overall TA and the availability of macroeconomic statistics, as a proxy to gauge the impact of the TA provided. Meetings were also held with country officials who had participated in IMF training courses to seek views on the effectiveness of these courses.

\section{Summary OF Findings In MOZAMbiQue AND RWANDA}

\section{After emerging from their civil wars in 1992 and 1994, respectively,} Mozambique and Rwanda required some time to rebuild and create the requisite institutions, including the national statistical organizations (NSOs) to facilitate absorption of TA. The most critical constraints in both countries were resources - both financial and human. Conflicts had diverted funding and undermined the ability to recruit, train, equip, and retain skilled personnel, which plays a vital role in the transfer of expertise via TA. Moreover, without a stable staff, the countries had not been able to develop frameworks and organizations that help to institutionalize the accumulated knowledge. Accordingly, the recovery not only required mobilization of resources but also the creation of legal frameworks, among other things, to permit the establishment of autonomous NSOs. The NSOs and other agencies, in turn, helped to anchor the broader efforts to enhance awareness of the importance of statistics (e.g., within poverty reduction strategies-PRSPs) and build the momentum for reforms (Boxes 1 and 2).

7. The anchor role of the NSOs can be seen in the number of important activities they play in statistical capacity building and reforms. First, NSOs, are responsible for compiling a large part of the demographic, social, and economic statistics, including national accounts and price statistics. These responsibilities entail a central role in undertaking surveys, censuses, and a part in the development and maintenance of administrative data systems, which altogether provide important source data for macroeconomic statistics, especially real sector and BOP data.

\footnotetext{
${ }^{4}$ The recognition of the importance of legal and institutional frameworks had also emerged at the international level through statistical initiatives at the Fund and other organizations. A good example is the July 2001 data quality assessment framework (DQAF, see http://www.imf.org/external/np/sta/dsbb/2001/supp.htm) and its subsequent update in July 2003.
} 


\section{Box 1. Mozambique and Rwanda: Political and Economic Settings}

\begin{tabular}{|c|c|c|}
\hline Key Developments & Mozambique & Rwanda \\
\hline \multirow[t]{2}{*}{ Political milestones } & $\begin{array}{l}\text { War for independence, 1964-75. } \\
\text { Independence, June } 25,1975 .\end{array}$ & Civil war, 1990-94. \\
\hline & Civil war, 1976-1992. & Genocide, 1994. \\
\hline \multirow[t]{2}{*}{ National statistical organizations } & $\begin{array}{l}\text { Ministry of Finance, established } \\
\text { in 1975, and incorporating a } \\
\text { National Directorate of Statistics } \\
\text { (NDS). }\end{array}$ & $\begin{array}{l}\text { Ministry of Finance and Economic } \\
\text { Planning established in } 1960 \text { and } \\
\text { incorporated the Direction Statistique } \\
\text { (DS). }\end{array}$ \\
\hline & Central bank established in 1975 & Central bank established in 1960 \\
\hline Statistical framework & $\begin{array}{l}\text { In } 1996 \text {, the NDS was transformed } \\
\text { into an autonomous Instituto } \\
\text { Nacional de Estatistica (INE, Laws } \\
\text { No. } 7 / 96 \text { and 9/96). Official national } \\
\text { statistics is coordinated by the High } \\
\text { Council of Statistics, presided over } \\
\text { by the Prime Minister and } \\
\text { comprising the President of the INE, } \\
\text { representatives from ministries, two } \\
\text { from universities, and three from the } \\
\text { private sector. }\end{array}$ & $\begin{array}{l}\text { Statistical Act approved by Parliament } \\
\text { in 2005, enabling the establishment of } \\
\text { the autonomous National Institute of } \\
\text { Statistics of Rwanda (NISR) from the } \\
\text { DS in } 2006 \text {. }\end{array}$ \\
\hline $\begin{array}{l}\text { Poverty reduction strategy paper } \\
\text { (PRSP) }\end{array}$ & $\begin{array}{l}\text { The first PRSP called PARPA } \\
\text { covered 2001-05 and a second- } \\
\text { generation PARPA II, which } \\
\text { covers } 2006-10 \text {, but has been } \\
\text { progressively revised and now } \\
\text { covers 2008-10. It highlights the } \\
\text { importance of statistics in } \\
\text { monitoring its implementation and } \\
\text { acknowledges the INE's central role } \\
\text { within the national statistical system } \\
\text { (NSS). Funding for statistical } \\
\text { reforms is fully incorporated in } \\
\text { PARPA II's medium-term } \\
\text { expenditure framework (MTEF). }\end{array}$ & $\begin{array}{l}\text { The first PRSP was launched in June } \\
\text { 2002. In September 2007, the second } \\
\text { generation PRSP - the Economic } \\
\text { Development and Poverty Reduction } \\
\text { Strategy (EDPRS, 2007-12) was } \\
\text { launched. It highlights the priority of } \\
\text { monitoring and the key role of the } \\
\text { NISR in such an exercise. However, } \\
\text { the PRSP process has yet to cost the } \\
\text { requisite statistical reforms and } \\
\text { incorporate their funding into the } \\
\text { MTEF. Absent prioritization and } \\
\text { funding for statistical reforms, it is } \\
\text { unlikely the planned improvement in } \\
\text { statistical capacity and the PRSP } \\
\text { monitoring exercise will be achieved. }\end{array}$ \\
\hline $\begin{array}{l}\text { National Statistical Strategic } \\
\text { Plans }\end{array}$ & $\begin{array}{l}\text { The first and second Statistical } \\
\text { Strategic Plans covered 1998-2002 } \\
\text { and 2003-07, respectively. The third } \\
\text { plan (2008-12) is a near state-of- } \\
\text { the-art plan. It was developed } \\
\text { through a comprehensive } \\
\text { participatory process (data } \\
\text { producers, users, and donors), and is } \\
\text { fully integrated into PARPA II to } \\
\text { facilitate adequate funding and } \\
\text { effective monitoring of PARPA II. }\end{array}$ & $\begin{array}{l}\text { The first Statistical Strategic Plan for } \\
\text { the development of the national } \\
\text { statistical system covered 2003-07. } \\
\text { Preparations for the National Strategy } \\
\text { for the Development of Statistics } \\
\text { (NSDS, 2009-13) is in an advanced } \\
\text { stage, but is not synchronized with the } \\
\text { EDPRS. Thus, the full scope of the } \\
\text { requisite statistical reforms to ensure } \\
\text { adequate monitoring of the EDPRS } \\
\text { has yet to be established, costed, and } \\
\text { prioritized. Funding for the NSDS has } \\
\text { yet to be established. }\end{array}$ \\
\hline
\end{tabular}




\begin{tabular}{|c|c|c|}
\hline \multicolumn{3}{|c|}{$\begin{array}{l}\text { Box 2. STA's Technical Assistance Evaluation Missions to Mozambique and Rwanda: } \\
\text { Assessment, Risks, and Priorities Going Forward }\end{array}$} \\
\hline \multicolumn{3}{|c|}{ Mozambique and Rwanda } \\
\hline $\begin{array}{l}\text { Overall } \\
\text { assessment }\end{array}$ & \multicolumn{2}{|c|}{$\begin{array}{l}\text { There was expressed either a favorable or very favorable opinion on the various aspects of the } \\
\text { TA received in both countries: } \\
\text { - The TA provided has been very useful and met the countries' priority needs. } \\
\text { - The TA provided by long-term experts stationed in the countries and by short-term missions is } \\
\text { considered the most effective form of TA, particularly when accompanied by detailed action } \\
\text { plans to implement the recommendations. } \\
\text { - TA missions provided applied training in the areas covered, although the length of the training } \\
\text { (especially for balance of payments (BOP) in the case of Rwanda) is considered too short. } \\
\text { - The TA has facilitated the provision of regular statistics needed for the IMF's African } \\
\text { Department (AFR) and for publication in International Financial Statistics. } \\
\text { - In general, TA has facilitated the formulation of economic policies and the dissemination of } \\
\text { more and better-quality statistics, and improved dissemination practices. }\end{array}$} \\
\hline & \multicolumn{2}{|c|}{$\begin{array}{l}\text { Mozambique and Rwanda started participating in the GDDS in } 2003 \text { and have used the GDDS } \\
\text { metadata disseminated in the Dissemination Standards Bulletin Board (DSBB) and national } \\
\text { sites to facilitate some coordination of the TA received by each country. The institutional } \\
\text { capacity to produce macroeconomic statistics has been substantially strengthened. }\end{array}$} \\
\hline & Mozambique & Rwanda \\
\hline $\begin{array}{l}\text { Key statistical } \\
\text { achievements }\end{array}$ & $\begin{array}{l}\text { - Full adoption of international methodologies } \\
\text { for compiling macroeconomic statistics, except } \\
\text { for government finance statistics (GFS). } \\
\text { - Rebasing of the national accounts (NA) to a } \\
\text { new base year (2003). } \\
\text { - Compilation of quarterly NA and BOP } \\
\text { statistics, and annual international investment } \\
\text { position (IIP) statistics. } \\
\text { - Establishment of a business register. } \\
\text { - Adoption of the standardized report forms for } \\
\text { the compilation of monthly monetary and } \\
\text { financial statistics (MFS). } \\
\text { - Preparation of strategic statistical plans, fully } \\
\text { integrated with the government programs and } \\
\text { coordinated with main partners providing } \\
\text { assistance in the statistical area. }\end{array}$ & $\begin{array}{l}\text { - Creation of the National Institute of } \\
\text { Statistics of Rwanda in } 2006 . \\
\text { - Adoption of the international } \\
\text { methodologies, except in GFS. } \\
\text { - Adoption of a legal framework for GFS in } \\
2006 \text { and of a legal text in } 2007 \text {. } \\
\text { - Publication of a detailed financial } \\
\text { management manual and approval of a chart } \\
\text { of accounts in } 2007 \text {. } \\
\text { - Introduction of a quarterly publication of a } \\
\text { producer price index (PPI); work in } \\
\text { progress. } \\
\text { - Adoption of the standardized report form } \\
\text { for the compilation of MFS. }\end{array}$ \\
\hline $\begin{array}{l}\text { Evaluation of } \\
\text { STA courses }\end{array}$ & \multicolumn{2}{|c|}{$\begin{array}{l}\text { In general, the participants in the IMF training courses are satisfied with the training received } \\
\text { through courses, seminars, and workshops, and find this training very useful to their work. The } \\
\text { case studies offered during the courses gave them a deeper understanding of the theoretical part } \\
\text { of the courses. Below are some observations/suggestions from the participants: } \\
\text { - The longer courses on methodology are more beneficial than the shorter courses or seminars. } \\
\text { Shorter courses did not allow the participants to fully internalize the knowledge received and } \\
\text { benefit from the experience of colleagues from other countries. } \\
\text {-STA should follow up with the participants to ensure that they have made improvements in } \\
\text { their work. }\end{array}$} \\
\hline
\end{tabular}




\begin{tabular}{|c|c|c|}
\hline \multicolumn{3}{|c|}{ Mozambique and Rwanda } \\
\hline $\begin{array}{l}\text { Risks to the } \\
\text { quality and } \\
\text { sustainability of } \\
\text { official } \\
\text { macroeconomic } \\
\text { statistics }\end{array}$ & \multicolumn{2}{|c|}{$\begin{array}{l}\text { Common risks to the quality and sustainability of the official macroeconomic statistics are: } \\
\text { - Inadequate resources, especially at the national statistical organizations (NSOs) and, to some } \\
\text { extent, at the ministries of finance to generate and maintain source data and undertake } \\
\text { coordinating activities. } \\
\text { - Inadequate utilization of the GDDS framework to coordinate activities, including regular } \\
\text { updates of metadata, and plans for improvement to prioritize reforms and TA needs. } \\
\text { - The heavy reliance on external financing for statistical activities, especially at the NSOs. } \\
\text { - Lack of dedicated units to compile GFS in both countries, which could be targeted with TA. } \\
\text { - Pending work on national strategic plans for statistics to integrate the role of the Ministry of } \\
\text { Finance (MoF) and its activities in GFS into the national reform priorities (Mozambique) and } \\
\text { into the medium-term expenditure framework of the PRSP to ensure adequate funding } \\
\text { (Rwanda). } \\
\text { - Limited coordination among the data-producing institutions and with data users. } \\
\text { - For non-English-speaking countries, access to TA and training remains a challenge. }\end{array}$} \\
\hline \multirow{5}{*}{$\begin{array}{l}\text { Priorities } \\
\text { going forward }\end{array}$} & \multicolumn{2}{|c|}{$\begin{array}{l}\text { Overall priority: Consolidate gains in the capacity to produce and disseminate quality statistics } \\
\text { with emphasis on the production and dissemination of quarterly GFS and public debt } \\
\text { statistics. }\end{array}$} \\
\hline & Mozambique & Rwanda \\
\hline & $\begin{array}{l}\text { National accounts statistics } \\
\text { - Improve the quality of source data for } \\
\text { compiling NA. } \\
\text { - Strengthen the methodological soundness } \\
\text { and the statistical techniques for compiling } \\
\text { annual and quarterly NA. } \\
\text { Price statistics } \\
\text { - Expand the geographic coverage of the } \\
\text { consumer price index (CPI). } \\
\text { - Improve software used and reinforce } \\
\text { regional offices' human and technological } \\
\text { resources. }\end{array}$ & $\begin{array}{l}\text { Real sector statistics } \\
\text { - Improve source data and set up systems to } \\
\text { review the NA, CPI, and PPI. } \\
\text { - Finalize the ongoing work on rebasing the } \\
\text { PPI on manufacturing sector activities, which } \\
\text { will include mining and quarrying, electricity, } \\
\text { gas, and water, and begin monthly publication. } \\
\text { - Compile the quantity and volume industrial } \\
\text { production index. } \\
\text { - Compile a price and production index for the } \\
\text { construction industry. Compile a service sector } \\
\text { index. } \\
\text { - Estimate quarterly GDP. }\end{array}$ \\
\hline & $\begin{array}{l}\text { Government finance statistics } \\
\text { - Set up a dedicated unit to compile GFS and } \\
\text { clarify the role of the MoF within the NSS. } \\
\text { - Start compiling and disseminating quarterly } \\
\text { GFS fully aligned with the Government } \\
\text { Finance Statistics Manual 2001(GFSM 2001). } \\
\text { - Report quarterly GFS to the STA on a timely } \\
\text { basis. }\end{array}$ & $\begin{array}{l}\text { Government finance statistics } \\
\text { - Improve the existing chart of accounts and } \\
\text { classification to comply with GFS and ensure } \\
\text { that the staff can produce GFS on their own. } \\
\text { - Develop a strategic plan to migrate to } \\
\text { GFSM 2001. }\end{array}$ \\
\hline & $\begin{array}{l}\text { Monetary and financial statistics } \\
\text { - Extend the coverage of the MFS to the other } \\
\text { financial corporations and start compiling } \\
\text { transaction data and financial statistics. }\end{array}$ & $\begin{array}{l}\text { Monetary and financial statistics } \\
\text { - Fully implement the Monetary and Financial } \\
\text { Statistics Manual, } 2000 \text { (MFSM) and including } \\
\text { compilation of flow data. }\end{array}$ \\
\hline
\end{tabular}




\begin{tabular}{|c|c|}
\hline \multicolumn{2}{|c|}{$\begin{array}{l}\text { Box 2. STA's Technical Assistance Evaluation Missions to Mozambique and Rwanda: } \\
\text { Assessment, Risks, and Priorities Going Forward }\end{array}$} \\
\hline \multicolumn{2}{|c|}{ Mozambique and Rwanda } \\
\hline $\begin{array}{l}\text { Balance of payments statistics } \\
\text { - Improve the methodological soundness and } \\
\text { the statistical techniques for compiling annual } \\
\text { and quarterly BOP. } \\
\text { - Compile quarterly IIP statistics. }\end{array}$ & $\begin{array}{l}\text { - Implement the integrated monetary database } \\
\text { (IMD) that meets the needs of different } \\
\text { partners. } \\
\text { Balance of payments statistics } \\
\text { - Produce better estimates for BOP } \\
\text { transactions. } \\
\text { - Compile BOP and IIP statistics based on } \\
\text { information from the survey and financial } \\
\text { statements of enterprises. }\end{array}$ \\
\hline
\end{tabular}

Second, in part to fulfill their responsibilities, the NSOs have to play a coordinating role among other data-producing agencies (e.g., the central bank, the ministry of finance, and other line ministries), ${ }^{5}$ as well as with donors and data users. This coordination is critical to reforms, absorption, and retention of TA. Lastly, NSOs play important roles in the advocacy for statistics (to promote public awareness), not least through participatory national statistical strategic plans with links to PRSPs that are essential to mobilize resources in the context of the medium-term expenditure frameworks (MTEFs). ${ }^{6}$ Availability of adequate medium-term national budgetary resources is important to the sustainability of statistical reforms and the complementary inputs of supporting TA.

\section{Notwithstanding a longer period of political conflict, Mozambique had an earlier} start on introducing the basic reforms and statistical capacity building and has made more progress. Accordingly, both the latest versions of the PRSP and Mozambique's Statistical Strategic Plan have placed the Instituto Nacional de Estatistica (INE) in a pivotal position to guide reforms, and appear to have made a strong case for support from both national and donor resources. In practice, while the INE has made significant progress with mobilizing resources, such resources are still not adequate for the increased responsibilities that have come with the expanded territory. Rwanda's progress with institutional capacity building has taken a very similar route to that in Mozambique but has a relatively long way to go to complete the latest Statistical Strategic Plan and integrating it into the PRSP and its MTEF. In practice, the National Institute of Statistics of Rwanda (NISR), although a recent

\footnotetext{
${ }^{5}$ An important aspect of this coordinating role is related to the NSOs' work in compiling national accounts based on the System of National Accounts 1993 (1993 SNA). The latter sets the overarching conceptual framework for all macroeconomic statistics. For details, see The System of Macroeconomic Accounts Statistics, IMF Pamphlet Series No. 56.

${ }^{6}$ As a public good, statistics are undersupplied by the market and active advocacy is therefore important to ensure adequate public funding to enhance the supply of data to policymakers and market participants.
} 
recipient of an infusion of resources, still has some distance to go to acquire comparable resources.

9. The experience with reforms and the impact of TA in the various statistical areas differ significantly from Mozambique to Rwanda and even within each country. This reflects not only the differences in the amount and mode of TA delivery, but also the legal and institutional legacies, resources, and source data available to the TA recipient statistical agencies.

10. Mozambique benefited from two data ROSC missions and received a larger volume of TA, a large part of which was through its participation in the two GDDS projects. The TA also included a regional GDDS and national accounts resident advisor, whose location in Maputo enabled the country to receive sustained TA in these areas. On the other hand, while Rwanda received less TA, it benefited from significantly more training, in large part because of better availability of INS and STA regional English and French courses. To make up for the limited number of Portuguese courses, STA organized a regional course on national accounts in Maputo and resorted to collaboration with the Bank of Portugal $(\mathrm{BoP})$ to provide training to Portuguese-speaking African officials at its headquarters in Lisbon. The more formalized project-linked TA and better collaboration with other TA providers and donors in Mozambique (aided by the hiring of a full-time donor-funded TA coordinator) also provided additional benefits to Mozambique, including a better framework to underpin the assessment of the results.

\section{TA in both Mozambique and Rwanda appears to have been most effective and} sustainable in balance of payments statistics (BOP) and monetary and financial statistics (MFS), since the central banks have had more resources and stable staff to absorb and retain the transfer of knowledge. In both countries, despite the provision of more TA in the real sector, progress has been hampered by limited resources, especially staff resources at the NSOs. The NSOs were also limited in their role of coordinating other statistical agencies, which largely account for delays in updating the GDDS metadata and plans for improvement. Moreover, there remains considerable scope for improving coordination, both among the national statistical agencies and with data users, in order to enhance data dissemination in both countries.

\section{TA in GFS was problematic in both Mozambique and Rwanda, in large part} because the respective ministries of finance did not have dedicated units and adequate staff for effective absorption. Ironically, the two countries have received considerable TA from the Fund's Fiscal Affairs Department (FAD) and from donors to strengthen public finance management (PFM). Even though TA in PFM and GFS have somewhat different focus, there is a common ground, which could generate significant synergies. This common ground was not fully coordinated to ensure that the improved availability of data meets international methodological statistical standards. 


\section{MozambiQue}

\section{A. Introduction}

13. Mozambique had a weak statistical infrastructure when the country became independent in 1975, and this infrastructure further deteriorated during the ensuing protracted civil war through 1992. Mozambique started receiving IMF financial assistance in the mid-1980s, and the first multisector statistical assessment mission was undertaken in the early-1990s. This mission found out that, as a post-conflict country, Mozambique had very limited capacity to absorb TA in macroeconomic statistics and recommended the allocation of more resources to statistical activities. The setting up of the INE in 1996 was an important step in the authorities' efforts to rebuild the country's statistical system in partnership with several donors, including the IMF.

\section{A comprehensive STA TA program was not formally launched until after a} national statistical strategy had been developed starting in 1998 with inputs from all stakeholders, including donors, who provided most of the requisite resources for the INE. ${ }^{7}$ The improvements in the institutional environment and the increased allocation of resources for compiling macroeconomic statistics addressed important weaknesses in the prerequisites for implementing an STA TA and training program.

\section{B. Inputs of the Program}

\section{Ownership of the program}

15. While initially the authorities' requests for STA TA often arose from mutually perceived needs and tended to be initiated by STA staff, efforts were always made to ensure that ownership was shared with the authorities. The authorities' ownership of the TA program increased over time, mainly following the decision to participate in the GDDS, ${ }^{8}$ and the launching of the IMF-sponsored regional project for strengthening the statistical capacity in Portuguese-speaking African countries (Lusophone Africa GDDS Project). ${ }^{9}$ More recently, the TA program was determined based on the priorities mutually discussed with the authorities in the context of the IMF-supported programs and taking into account resource

\footnotetext{
${ }^{7}$ Since 1998, Mozambique has prepared Five-Year Statistical Plans, the most recent of which is the Strategic Plan for the National Statistics System, 2008-12.

${ }^{8}$ Participation was formalized in November 2003 with the posting of the metadata on compilation and dissemination practices, and plans for statistical improvement on the IMF's Dissemination Standards Bulletin Board (DSBB).

${ }^{9}$ The Lusophone Africa GDDS Project 2002-05 was financed by the Japan Administered Account for Selected Fund Activities (JSA) at the IMF. The stationing of the national accounts resident advisor in Maputo from August 2005 to August 2006 was also financed by the JSA.
} 
constraints. A good example of this process was the preparation of TACSNs during FY 2006-07 for Mozambique with inputs provided by the authorities and AFR.

\section{Strategy of the program}

16. The authorities participated actively in the identification of the priorities for assistance under the Lusophone project and developed comprehensive action plans to improve most data categories, disseminated on the Dissemination Standards Bulletin Board (DSBB). The TA provided to Mozambique consisted mainly of capacity-building activities with a relatively small portion of the activities emanating from requests for shortterm help in resolving the most immediate data issues affecting the IMF surveillance or program monitoring. The capacity building focuses on strengthening human capacity through knowledge and skills transfer and institutional capacity through organizational and methodological advice. The TA was provided in Portuguese, mainly by native-speaking experts.

17. Mozambique agreed to participate in the external sector module of the second phase, DFID-financed GDDS Project (2006-09). Priorities for this assistance were finetuned with the authorities during the Cape Town workshop in September 2006, where the second-phase project was launched. The fact that the TA under this project is provided only in English has precluded Mozambique from benefiting from the TA in areas other than the BOP.

\section{Interaction with other TA providers}

\section{Emphasis was placed on bringing together donors and partners involved in} providing assistance in areas of common interest. The IMF has played an important role in this area by hosting a donor-financed TA country coordinator in the Resident Representative's office in Maputo (see Box 3). This allowed the TA to be better sequenced and to maximize the synergies, taking into account the country's priority work programs and absorptive capacity. Coordination with other TA providers also was close under the Japanese-funded Lusophone Africa GDDS Project, in particular, with the Scandinavian and Italian programs, providing substantial resources and TA to the INE. The frequent visits by the GDDS and national accounts advisor facilitated the use of the GDDS plans for improvement to better coordinate the assistance with other TA providers. Moreover, the IMF has collaborated with DFID and the World Bank (co-executor of the DFID-financed GDDS Project) in providing TA to Mozambique. STA has also collaborated with Portugal through the Bank of Portugal and the Portuguese NSO to identify TA experts and in providing training to Mozambican officials. 


\section{Box 3. Mozambique's Technical Assistance Coordinator and the Role of the IMF}

Drawing on its experience with the Technical Cooperation Action Plan (TCAP) in Cambodia, where local staff had been recruited to coordinate the work of short-term experts and with donors, the IMF collaborated with donors, notably DFID, the Swiss State Secretariat for Economic Affairs (SECO) and the Danish International Development Agency (DANIDA) to establish a TA coordinator in Mozambique. The IMF offered to attach the TA coordinator to its Resident Representative Office in Maputo, while the donors, particularly DFID, offered to fund the position, initially for four years through April 2008, and subsequently, Ireland for another year. The role of the TA coordinator was envisaged as:

- $\quad$ To coordinate all project-related activities at the local level, provide support to short-term experts (and headquarters TA missions) in securing meetings with counterparts and obtaining needed information in advance, and generally smoothing things out on the administrative side. Such activities were seen as instrumental in permitting headquarters staff to focus more effectively on backstopping work;

- $\quad$ support the Government in the donor-coordination role, which, in the case of Mozambique, also included chairing a number of projects' Steering Committees. Most donors have active local offices and the TA coordinator was expected to work closely with the staff and thereby avoid duplication of efforts, while promoting TA synergies;

- $\quad$ Liaise with headquarters staff in the TA and area departments (e.g., on the tax reform project), to ensure continuity with TA and related reforms and facilitate a smooth execution of such project and other activities from Washington.

To date, the IMF staff and donors concur that the TA coordinator has contributed to better coordination of the work of TA advisors and donors, more effective planning of short-term visits and TA interventions and, in general, smoother execution of at least two complex project yielding positive results. Moreover, the TA coordinator was also instrumental in mobilizing additional donor resources to fund reforms in the tax and PFM areas. The TA coordinator assisted with negotiations on the multi donor common fund, better gathering of information and assisting program missions, and more recently, enabled the negotiations of the Memorandum of Understanding under which Mozambique agreed to pay for follow-up of FAD TA in FY 2009. Without such input, it would have taken a lot of time and effort to conclude this arrangement.

\section{Cooperation agreements have been crucial to undertaking training courses targeted to Portuguese-speaking countries. BOP and MFS courses targeted to African} Portuguese-speaking countries were undertaken in close collaboration with the Bank of Portugal. This collaboration has contributed to mitigating the costs of the training activities to the IMF, while providing an opportunity for representatives from the Bank of Portugal to make presentations on different aspects of data compilation and statistical auditing procedures. These presentations have always been well received by the participants. 


\section{Design of action plans}

20. The Project Management System (PMS) was the backbone underpinning the TA provided in the statistical area. ${ }^{10}$ The GDDS plans for improvement provided the general background for the TA in each topical area. Comprehensive analyses of the institutional framework and statistical practices undertaken in each topical area formed the basis for translating the GDDS plans for improvement into work programs with deliverables and timetables. The initial analyses were guided by the Data Quality Assessment Framework for the respective dataset. The work programs were summarized in action plans, which proved instrumental for the authorities to mobilize and channel other donors' assistance to implement the priorities identified. The ROSC data module missions undertaken in mid-2002 and in 2005 provided additional guidelines for the development of the TA program.

\section{Selection of experts}

21. The selection of experts was guided by the need to provide TA, including on-thejob training, in the official language (Portuguese). This key criterion responded to the authorities' main concern of ensuring the effectiveness of the TA provided, particularly owing to the absence of translations of the statistical manuals and compilation guides in all areas except NA.

\section{The identification of the experts relied mainly on collaborative understandings} reached with partner institutions in Portugal. This entailed mostly the Bank of Portugal and the Portuguese NSO. This approach reflected the dearth of Portuguese-speaking staff in STA and the fact that STA's expert roster included only one expert meeting the language criteria. In practice, TA was provided largely by short-term experts ( 29 missions) and one long-term expert, while STA staff undertook just three missions. As a result, backstopping (reviewing the work of and providing guidance to) the new experts with no prior experience working with the IMF was particularly challenging, and entailed close contacts and information sharing with the country teams in AFR, in other TA departments, and the World Bank.

\section{The authorities have indicated their high satisfaction with most of the staff and} experts involved in the program (Appendix Table 3). In general, the major common factor stressed by the authorities in positive assessments of the experts was the experts' direct operational experience and ability to transfer that experience. The GDDS and NA expert was particularly experienced and, at the authorities' request, was retained as NA expert in Maputo

\footnotetext{
${ }^{10}$ The PMS was developed in STA and provided the foundation for the subsequent Fundwide Technical Assistance Information Management System (TAIMS).
} 
after the end of the Lusophone project. The assistance provided in price statistics gave way to further bilateral assistance provided by the Portuguese National Institute of Statistics, and the transition to an English-speaking BOP expert was smooth and productive. The fact that the assistance in MFS was provided by STA staff facilitated the introduction of the standardized report forms (SRFs) and the establishment of the integrated monetary database (IMD) now in use for publication and program-monitoring purposes. The only case of less-than-positive expert evaluation was mainly ascribed to the expert's inability to transfer knowledge in GFS during an earlier mission in 2003. However, insufficient preparatory work on the part of the receiving institution and the lack of a well-defined mission counterpart also contributed to the less-than-positive outcome. The prompt action taken to remove the expert from the STA roster of experts was viewed as a demonstration of STA's genuine interest in the success of the TA program. However, little progress has been made to facilitate the absorption of the TA provided in GFS in more recent years.

\section{Modalities of delivery}

\section{STA TA was delivered through a combination of staff from IMF headquarters} and of experts identified by STA. During 2000-08, 32 missions were undertaken in the various statistical areas, and a resident national accounts advisor was stationed for one year in Mozambique. Most of the experts have operational experience in compiling macroeconomic statistics at national institute of statistics, central banks, and ministries of finance, although most of them had no previous experience as STA experts. The frequency of the TA missions reflected mainly the authorities' area-specific needs and pace of implementation of the action plans, except for the TA in GFS, which, in fact, started only in mid-2005. Delays in implementing the integrated management and financial information system and inadequate resources were contributing factors to the limited TA in this area.

25. The TA was delivered predominantly by experts, reflecting both the shortage of Portuguese-speaking STA staff and the inability to finance IMF staff using external sources of financing. The TA program has been delivered through a combination of a series of two-week visits, longer visits from the GDDS and NA peripatetic advisor, and the stationing of a regional long-term NA advisor in Maputo. This combination has served to emphasize the fact that the counterparts have to build on the transfer of knowledge to implement the action plans agreed, while allowing for a more hands-on and one-on-one involvement in more complex areas, where more permanent assistance is needed.

\section{Particular efforts have been made to ensure continuity in both STA staff and} experts involved with the TA program. The benefits of this continuity are clear in the good relationships that have developed between staff and experts and their Mozambican counterparts. The benefits are also clear in light of the initial challenges of backstopping experts with no prior experience working for STA. 
27. Other forms of assistance included statistical courses undertaken mostly in Portuguese, GDDS presentations at local and regional conferences/workshops, and short seminars conducted during the missions. During 2000-08, 27 officials participated in courses in macroeconomic statistics. Courses and short seminars have been supported with extensive training material in Portuguese tailored to the country's conditions. The majority of the Mozambican officials participated in STA training programs targeted to Portuguesespeaking countries; meanwhile, owing to language barriers, only a limited number have attended INS courses.

\section{Monitoring of program implementation}

28. Monitoring of the TA program implementation was mainly focused on ascertaining the status of implementation of the missions' recommendations, as reported by the countries using the relevant PMS matrices. Monitoring relied also on the information provided periodically by the GDDS peripatetic advisor, and the information provided by each follow-up mission. The experts were evaluated taking into account feedback from the authorities.

29. In 2004, an internal STA TA evaluation of the Lusophone Africa GDDS Project was undertaken based on a questionnaire sent to the counterpart authorities, followed by a short staff visit to discuss the results of the questionnaire and the priorities for the TA program in the period ahead. In particular, the authorities were asked to rate (i) the effectiveness of the GDDS as a framework for the project in improving macroeconomic statistics; (ii) the effectiveness of the project approach in meeting its stated outputs; (iii) the prospects for meeting the project goal and purpose; and (iv) the role of the GDDS advisor. Most of the responses fell, on average, between the "totally effective" and "rather effective" scores, indicating a level of appreciation for the project that was also conveyed in the written commentary and buttressed during the staff visit.

30. While Mozambique has used a sizable amount of TA to make significant progress in a number of areas, it still has some way to go in strengthening institutional capacity to produce high-quality statistics. A judicious allocation of resources in support of the medium-term Statistical Strategic Plan is key to achieving this objective. Better coordination among national statistical agencies using the GDDS framework and enhanced training are essential to facilitate the absorption of TA and upgrade the quality of the macroeconomic statistics produced.

31. The INE has prepared a comprehensive Statistical Strategic Plan (2008-12), which is well integrated with the government poverty reduction strategy-PARPA II (2008-10). However, resources are still a constraint in the implementation of the Strategic Plan, particularly with regard to the production of timely and quality national accounts and prices statistics. Equally noteworthy is the fact that this plan does not cover the statistical role 
of the Ministry of Finance (MoF), namely with regard to the compilation of GFS and public debt data. This omission is mainly because the statistical function of the MoF continues to be outside the umbrella of the country's national statistical system (NSS) coordinated by the INE. Moreover, the MoF lacks a unit dedicated to compiling GFS and liaising with the INE and Bank of Mozambique (BoM) in coordinating the production and dissemination of data.

32. The authorities indicated satisfaction with the mix of the TA program They were very appreciative of the long-term expert in NA, both for her expertise and knowledge of local conditions and the very effective training she provided. The authorities rated the staff and peripatetic experts highly in terms of their technical skills and understanding of local conditions. However, they felt that the missions could have benefited from a longer duration to allow more on-the-job training. Courses in statistics were very beneficial but, in general, also could have been longer, with more time dedicated to practical examples and case studies.

33. Data users acknowledged improvements in the quality of, and access to, data but saw a need for further improvement. In particular, some commented on the need to enhance the quality and coverage of data; the latter at both the national and regional levels and over longer time periods. They indicated that they would welcome improved data websites, a one-stop shop for access to all relevant macroeconomic and social statistics from the main data producers, and better outreach by the statistical agencies to improve the dialogue on data quality and access. The absence of GFS was noted as a significant gap in the country's macroeconomic statistics.

\section{Outputs of the Program}

\section{Implementation of action plans}

\section{There has been substantial implementation of the action plans in all} macroeconomic statistics, except for GFS, where progress has been very slow. Although the public management information system in place since late 2007 would allow the compilation of high-quality GFS, ${ }^{11}$ shortcomings in the awareness of the importance of these statistics precluded a speedier pace of implementation of the action plan agreed in 2005 .

\footnotetext{
${ }^{11}$ The MoF has been implementing a major nationwide public finance management reform called SISTAFE, initially with substantial IMF TA and financed by a multidonor common fund. The reform is focusing on rolling out a government financial management information system (e-SISTAFE). e-SISTAFE has been rolling out to all line ministries at the central and provincial level since end-2007, and in 2008, the rollout to districts (33 districts out of a total of 128) began. The medium-term fiscal framework is also closely aligned with the PARPA II priorities. Separately, the government has been working with donors to introduce a second version of a system, called ODAMOZ II, to account for donor aid programs (most of them currently outside the government budget), which will eventually interface with e-SISTAFE to cover comprehensively the national
}

(continued...) 
35. NA are produced according to the System of National Accounts 1993 (1993 SNA). As a result of the IMF TA program and technical and financial assistance provided by other TA providers, the annual national accounts were rebased to 2003, and the compilation and dissemination of quarterly national accounts in constant prices started in 2007. In January 2008, the INE began disseminating monthly indicators on the economic climate, job expectations, and business confidence. The 2008 mission recommended strengthening the national accounts staff team, further methodological improvements of the annual and quarterly estimates, and more and better quality of monthly or quarterly indicators of industrial output, employment and income statistics, and foreign trade.

36. The consumer price index (CPI) geographical coverage was expanded to cover the three largest cities, and the source data improved significantly. A household income and expenditure survey and a census of the establishments were conducted in 2003, and the business register was established in 2004. The 2006 mission recommended further expanding the geographical coverage, strengthening information technology resources, and improving the CPI software. Resource constraints, which are more severe in the regions, continue to hamper timely processing of price data and, as a result, only the Maputo CPI is disseminated on a timely basis. In addition, efforts to extend the CPI coverage to the fourth largest city have been slow owing to technological and human resource constraints.

\section{MFS are compiled on the basis of the Monetary and Financial Statistics}

Manual, 2000 (MFSM) and Compilation Guide (2008) and are disseminated on a timely basis. Since December 2002, Mozambique started reporting monthly SRFs for monetary statistics based on the MFSM, and the monetary statistics integrated database serving AFR, STA, and the authorities' needs has been fully operational since mid-2006. Further improvements will encompass expanding the coverage of the monetary statistics to the other financial corporations and starting to compile financial statistics.

\section{Starting in 2004, the compilation of the BOP has been based on the Balance of} Payments Manual, fifth edition (BPM5). The BOP surveys were expanded to cover major direct investment enterprises, as well as the transportation, communications, and tourism sectors to improve source data. In 2008, and in collaboration with the INE, a quarterly BOP enterprise survey was launched with a significantly expanded coverage. Annual data on the international investment position have started to be compiled, albeit with limited coverage. The 2008 mission recommended further work to expand source data and validate their accuracy, including through the use of the existing International Transactions Reporting System.

budget system. With e-SISTAFE generating a growing amount of hitherto unavailable data, the MoF, however, has not yet put in place a compilation system of GFS to ensure consistency with international standards. 
39. Progress in GFS has been slow, reflecting delays in rolling out the new information management system and insufficient awareness of the importance of these statistics. The lack of a dedicated unit to compile GFS has hampered the absorption of the TA. During the evaluation mission, the authorities expressed their commitment to establish a statistical unit in the MoF dedicated to the compilation and dissemination of GFS as a starting point to increase their capacity to absorb TA in this area.

\section{Strengthening of institutional capacity}

40. The Mozambican authorities, the IMF staff and experts, and the representatives of the business community and civil society interviewed consider that there has been a substantial enhancement of the statistical capacity. The implementation of earlier action plans resulted in substantial improvements in data and metadata availability. The INE has grown in size and reputation and is well placed to coordinate the Statistical Strategic Plan in the development of the country's statistical system. The fact that the NSS is now fully integrated in the government's MTEF, through which donor funding is channeled, is likely to ensure that available resources are used to finance the statistical priorities identified in consultation with all stakeholders. Mozambique meets or exceeds most GDDS recommendations and is well positioned to make further progress toward subscribing to the Special Data Dissemination Standards (Appendix Table 4).

\section{Risks to the program}

41. While substantial progress has been made, there remain risks to the further enhancement of the statistical capacity. The first involves the capacity to attract and retain skilled staff, particularly at the INE. In the context of high staff turnover and the significant lead time needed to forge statistical competency, financial constraints and the ongoing review of autonomous agencies' staff remuneration raise serious concerns about the INE's ability to retain the most qualified staff and to recruit suitable candidates. Staff turnover continues to undermine efforts to strengthen statistical capacity, and makes it more difficult to absorb TA.

42. The second risk entails the fact that the bulk of the available funding for INE's work program comes from donors. This creates a challenge for the authorities to augment national budget resources to ensure sustainability of the reforms and the TA that supports them.

43. The third risk emanates from the challenges to provide TA, training, and training materials in Portuguese. Extending the TA provided under the DFID-financed project to Portuguese-speaking experts would help to minimize this risk. Taking full advantage of the cooperation understandings with Portuguese institutions, namely the INE and the Bank of Portugal, would not only allow the extension of the pool of experts but also enable offering training courses in Portuguese. The fact that, with the exception of the SNA 1993, there is no 
statistical manual or compilation guide translated into Portuguese further exacerbates the difficulties of ensuring a full transfer of skills in the statistical area. Insufficient commitment to producing GFS aligned with international best practices also continues to pose risks to the effectiveness of any TA in this area.

\section{RWANDA}

\section{A. Introduction}

44. Rwanda's statistical capacity was severely weakened by the civil war and genocide, which took place during 1990-94. These events weakened Rwanda's institutional capacity and made it difficult for the country to absorb IMF TA. TA absorption was particularly difficult in the real sector and GFS. Real sector statistics continue to rely heavily on donors' financial assistance and experts to finance surveys and produce data.

45. STA restarted the provision of TA to Rwanda in 2000. During that year, STA fielded two missions in BOP and MFS. However, to fully assess Rwanda's statistical needs, a multisector mission covering all four areas of macroeconomic statistics visited Kigali in 2003. The recommendations of the multisector mission, as well as those of previous and subsequent ones, provide part of the basis for this TA evaluation.

\section{In addition to the TA that the IMF has provided, donor assistance has been} crucial to improving statistical capacity in Rwanda. The United Nations Development Programme (UNDP) provides financing for real sector statistics surveys (agricultural survey) and for six advisors to the NISR. It also finances the national budget survey, and TA for the CPI and NA statistics. The African Development Bank (AfDB) assists the authorities with the elaboration of the National Strategy for the Development of Statistics (NSDS), which the NISR is in charge of. The DFID has also provided assistance in NA and CPI statistics. The World Bank, through its Statistics for Results Initiatives, provides support in management, reforms, and capacity building.

\section{The importance of statistics in monitoring poverty has been recognized in} Rwanda's PRSP — the Economic Development and Poverty Reduction Strategy (EDPRS). The first PRSP covered the period 2002-05, while the second covers the period 2007-12. These two documents provide for high priority for statistics and give the NISR an important role to play in improving the country's official statistics: in particular, the EDPRS indicates that the NISR "will provide a sound evidence-base for policymaking and results verification and its mandate should extend beyond surveys and censuses to include the exercise of quality control over information collected by line ministries, which are often the weakest link in the data chain." 


\section{B. Inputs of the Program}

\section{Ownership of the program}

48. Rwanda is committed to improving the statistical system. Since 2000, the authorities have requested a total of 17 TA missions to help implement reforms through a number of recommendations, including Rwanda's participation in the GDDS. Many of STA's recommendations were incorporated in the EDPRS and the national strategic plans for statistics. Moreover, they have sought financial assistance from donors to help finance censuses and surveys and TA delivery. STA missions and experts have been very well received, as they are seen as crucial in helping jump-start the statistical production and dissemination. Further evidence of the authorities' desire to take ownership of the program is demonstrated by the participation of Rwandan officials in IMF-sponsored courses and seminars since 2000. The authorities have also shown much interest in new STA initiatives, such as the proposal to refocus the GDDS toward enhanced data dissemination. However, despite these efforts, much remains to be done mainly because of the significant resource needs of a country that is still emerging from a serious conflict.

\section{Choice of areas for TA}

49. In general, the choice of $\mathbf{T A}$ reflects the needs in each specific statistical area. Of the 17 TA missions that have been conducted since 2000, three were on NA statistics, four on prices, six on BOP, two on GFS, and two on MFS. This breakdown and the access to donor TA in NA clearly shows the priority that has been given to real sector statistics and the NISR. However, the ability of the NISR to absorb this TA has been hampered by the shortage of qualified staff at this institution. A similar situation exists at the Ministry of Finance and Economic Planning (MINECOFIN), where, in the wake of the Civil Service restructuring starting in 2005, the staff is relatively new and needs training and hands-on TA to produce the data.

\section{Counterparts for the program}

50. Responsibility for compiling macroeconomic statistics falls on the NISR, the National Bank of Rwanda (NBR), and MINECOFIN. The NISR plays the role of coordinating agency and compiles data on national accounts statistics. It shares responsibilities with the NBR on the compilation of the CPI, the PPI, and external trade statistics. The NBR compiles and disseminates data on MFS and BOP, whereas the MINECOFIN is responsible for the compilation and dissemination of GFS data.

\section{Statistical production and dissemination are characterized by limited} coordination or collaboration among the data-producing institutions. Although the NISR plays the coordinating role among the data-producing agencies and hosts the national GDDS 
coordinator, statistical production and dissemination have not achieved the desired level of coordination to date. For example, Rwanda - a participant in the GDDS since June 2003has not updated its metadata, including plans for improvement, since they were first posted on the DSBB. In addition, the staff at MINECOFIN in charge of GFS is new and requires training and experience in order to liaise effectively with counterparts in the NISR and NBR. The mission discussed with the authorities the need for better coordination not only among the data-producing agencies but also with data users given the refocusing of the GDDS toward more emphasis on data dissemination through national summary data pages (NSDPs) and advance release calendars (ARCs). ${ }^{12}$

\section{Design of the action plan}

\section{To help monitor Rwanda's progress, STA mission reports include}

recommendations and time frames for their implementation. Subsequent TA missions assess the implementation of previous recommendations in the respective area and, on this basis, make new recommendations. In addition, as a GDDS participant, Rwanda has posted plans for improvement in each area of macroeconomic statistics with time frames, indicating also the TA and financing needed to achieve them. Unfortunately, the envisaged institutionalization of the GDDS to help with TA prioritization has yet to be realized, as these plans for improvement have not been updated since they were posted in June 2003.

\section{Interaction with other TA providers}

\section{Donor coordination of TA in statistics to Rwanda has been relatively good.}

Where TA activities overlap, efforts have been made to provide for common funding or to delineate clear-cut responsibilities while maintaining the essential collaboration. Thus DFID, the UNDP, and the European Union have been providing "basket" funding for some of the NISR activities, including improvements in source data and the compilation of NA and CPI data. This has enabled STA to use the East AFRITAC mostly to provide training in national accounts and the establishment of a producer price index (PPI). Rwanda receives TA from other organizations such as the World Bank and the AfDB, whose assistance has focused mainly on developing the NSDS.

\footnotetext{
${ }^{12}$ Following a review of the first 10 years of the GDDS and consultation with participating countries, the IMF has recommended a number of changes to the GDDS. For details, see Seventh Review of the Fund's Data Standards Initiatives (http://www.imf.org/external/np/pp/eng/2008/111908.pdf). These changes were approved by the Executive Board in December 2008, see IMF, Public Information Notice (PIN) No. 08/147, December $18,2008$.
} 


\section{Modalities of delivery}

54. STA TA to Rwanda has been delivered through a combination of STA staff, short-term experts, and the multisector sector statistical advisor based at East

AFRITAC. TA in real sector statistics and GFS was exclusively delivered through East AFRITAC, while TA in BOP was delivered through East AFRITAC and STA. TA in MFS was delivered exclusively through STA staff. In 2003, STA appointed a resident advisor to East AFRITAC, who has delivered TA in national accounts and price statistics to this group of countries, including Rwanda. The resident advisor has recruited experts to deliver TA in topical areas other than NA.

55. In addition to those trained by TA missions, STA has trained a total of 46 Rwandan officials in macroeconomic statistics since 2000. Prior to September 2008, the breakdown of the participants in IMF courses shows that most of them attended courses in MFS (14 officials) and BOP (16 officials). Seven officials have received training in government finance statistics, and only four in national accounts statistics. One official received training in external debt statistics and another one in financial soundness indicators. A breakdown by agency reveals that NBR officials received the most training (32 officials), followed by MINECOFIN (10 officials), and the NISR (4 officials). In October 2008, East AFRITAC and the UNDP conducted a one-week national accounts workshop for 10 newly recruited NISR staff. The majority of courses attended were in English and the balance in French, suggesting that access to English courses has enabled Rwanda to expand its reach for training.

56. It appears that limited staff and a more cumbersome bureaucratic approval process at the MINECOFIN and the NISR prevented more of their staff from participating in IMF courses. The evaluation mission proposed, and the authorities agreed, to streamline the training arrangements along those in the NBR, which has been more successful in providing training to participants. Rwandan officials have also participated in IMF- and East AFRITAC-sponsored local and regional workshops and seminars in NA, prices, and on the GDDS - all conducted in English. In April 2008, Rwanda's GDDS coordinator attended the joint DFID/STA workshop in Cape Town, South Africa, with the objective of eliciting views on the proposed refocusing of the GDDS on enhanced data dissemination.

57. The preferred mode of TA delivery varies from one topical area to another, depending on need. In a questionnaire that the mission submitted to the authorities prior to the TA evaluation mission, the preference expressed for TA delivery was not uniform among the three agencies that produce macroeconomic statistics. The NISR expressed a preference for both short-term visits of two weeks and for training and workshops. At the NBR, the preferred mode of TA delivery for BOP is for peripatetic visits by the same expert and short- 
term visits for MFS. At MINECOFIN, the preferred mode of TA delivery is through a resident expert.

58. These TA preferences clearly indicate that the NISR and MINECOFIN need more assistance. While MINECOFIN did not select training workshops as their preference, they indicated that they would prefer that the resident expert be involved in guiding the staff through their work. The authorities also noted that the two-week missions were too short to adequately cover the materials, and that the officials were not always able to implement the missions' recommendations. Nevertheless, they expect that future TA would become more effective because the requisite systems are now in place to absorb it.

59. With respect to BOP statistics, the NBR reported that TA missions provided applied hands-on training in the areas covered. They also indicated that such missions also helped to improve data quality. However, although training was provided during the missions, it was insufficient because the missions were very short and no BOP staff had previously participated in the full BOP comprehensive methodological courses (usually five weeks) at headquarters or at IMF regional training centers.

\section{Evaluation of STA courses}

60. In general, the participants in the IMF training courses were satisfied with the training that they had received through courses, seminars, and workshops. They found this training related well to the work that they do. The case studies offered during the workshops allowed them to deepen their understanding of the theoretical aspect of the course. The participants noted that the longer courses on methodology were more beneficial (since they laid a better foundation) than the shorter ones. In addition to the intensity of the shorter courses, these courses did not allow the participants to fully benefit from the experience of their colleagues from other countries. It was noted that access to both English and French courses and workshops enhanced training efforts.

61. To improve the effectiveness of the training, the participants suggested that the material covered be proportional to the duration of the courses. There was a stronger preference for longer courses. Moreover, STA should follow up more regularly with the participants to ensure that they have improved in their work. In addition, the participants who have attended shorter courses should not be disqualified for subsequent longer courses since all the material is not covered in the shorter courses.

\section{Outputs of the Program}

\section{Implementation of the action plans}

62. The authorities indicated that STA TA had been very useful in all areas of macroeconomic statistics (Appendix Table 6). In general, STA TA met Rwanda's priority 
needs. The 2003 multisector statistics TA mission was instrumental in facilitating Rwanda's participation in the GDDS. The GDDS plans for improvement that were compiled along with the metadata facilitated the channeling of STA's assistance into critical areas of macroeconomic statistics. Rwanda currently produces 20 of the 29 GDDS data categories, and the metadata for these categories are posted on the IMF's DSBB. However, the metadata and plans for improvement need to be updated regularly (Appendix Table 8).

63. A major accomplishment was the adoption of the Statistical Act in 2005, providing a basis for the creation of the NISR in September 2006. Before 2005, the Direction Statistique (DS) within the then MINECOFIN was responsible for real sector statistics. The medium-term strategic plan for the development of the NSS covering 2003-07 was updated and published and provided a useful context within which to establish the NISR. The NISR's major objective is to coordinate the role of the NSS. The NISR is preparing the first National Strategy for the Development of Statistics (NSDS), which will cover 2009-12.

64. Data quality, coverage, and dissemination practices have improved. The provision of data to AFR and to STA for publication in International Financial Statistics (IFS) has become more regular, although the use of the integrated correspondence system (ICS) to transmit these data to STA remains very limited. The role of TA in fostering coordination and interaction with donors was recognized in the areas of MFS and real sector statistics, but not in BOP statistics.

65. While the NISR is solely responsible for national accounts statistics, price statistics are jointly produced with the NBR. National accounts are produced broadly in accordance with the 1993 SNA. A joint effort of the NISR and the NBR has led to the establishment and publication of a quarterly PPI for manufacturing since 2005. A PPI for local market products and for exports is compiled with the support of East AFRITAC. The PPI was rebased to 2006, and its sample currently includes 120-130 enterprises from all sectors of economic activity, excluding construction. There are currently two indices of consumer prices, one for Kigali, produced by the NBR, and another one for the urban areas and the rest of the country, produced by the NISR. The index compiled by the NISR has been broadly accepted as the best measure of inflation in Rwanda. The Kigali index compiled by the NBR is considered as an additional useful gauge of inflation that normally becomes available earlier than the broader national index from the NISR. The NBR indicated that it would relinquish production of the CPI as soon as the NISR is able to produce a timely index for the entire country.

66. TA in real sector statistics is supported by donors, including the DFID, the UNDP, the European Commission, and the AfDB. These donors have established a basket fund to finance training, the purchase of equipment, surveys, censuses, and data analysis. The UNDP, East AFRITAC, and DFID have been involved with the production of NA, DFID the CPI, while East AFRITAC is involved in the production of the PPI. Other support to the 
NISR includes the appointment of six advisors in a range of statistical activities, and the management of projects under the basket fund, such as the agricultural survey and the national budget survey. The AfDB has provided assistance for the production of a still pending statistical master plan.

\section{Despite these efforts, several recommendations still had not been implemented}

by early September 2008. These include the (i) adoption of an action plan outlining the priorities for national accounts; (ii) development of modalities for cooperation between the NBR and NISR to jointly compile a national CPI for Rwanda; (iii) establishment of a national accounts unit within the NISR; and (iv) recruitment by the NISR of an adequate number of professional statisticians with experience in economic statistics. ${ }^{13}$ In their response to the questionnaire, the authorities indicated that further TA in NA, CPI, and PPI should focus on reviewing the systems put in place to produce these statistics, and to ensuring that they are well-functioning under local staff management.

68. Although some progress has been made in improving the GFS system, this area continues to represent an important challenge. Key achievements in this area include the adoption of the legal framework and the legal text in 2006 and 2007, respectively; approval of the chart of accounts in 2007; improvement of source data; and publication of consolidated financial statements for 2006-07. ${ }^{14}$ A major challenge at the MINECOFIN has been inadequate staff. Moreover, there is no unit dedicated to producing and disseminating GFS as well as to integrating the statistical reforms with the ongoing PFM reforms. However, in 2006, a civil service restructuring provided for a streamlined service and a substantial salary increase making the civil service competitive and addressing the previous problems of recruitment and retention of staff. The current problem is that its staff, including senior staff, are relatively new, and there is no institutional memory to recall the STA missions of 2003 (the multisector mission) and 2004. As a result, the responses to the GFS questionnaire were based on the most recent (May 2008 - a joint GFS and PFM mission funded by East AFRITAC) TA mission. Responses to the questionnaire indicated that TA provided so far has not had a significant impact on capacity building. Many of the recommendations of the 2003 multisector statistics mission have not been implemented.

\footnotetext{
${ }^{13}$ During October 2008, NISR hired some staff, who participated in a joint East AFRITAC/UNDP national accounts training workshop in Kigali. As part of the workshop, an action plan outlining the priorities for national accounts was discussed with the authorities and drafted.

${ }^{14}$ Rwanda has been separately implementing major public finance management (PFM) reforms, including the (i) introduction of an Organic Budget Law in September 2006; (ii) issuance of financial procedures manuals in May 2007 to complement the Organic Budget Law; (iii) approval of a new Law on Public Procurement in December 2007, under which the Rwanda Public Procurement Authority will be established; and (iv) finalization of a PFM strategy and action plan in September 2008.
} 
69. With respect to MFS, all the recommendations of the $\mathbf{2 0 0 3}$ multisector statistics mission were implemented. In addition, Rwanda has adopted the SRFs for reporting MFS data to STA and in the process has improved the timeliness and coverage of the data. The SRFs also reduce the burden of reporting data to the IMF by providing such data directly to STA, which then shares them with other departments. However, the NBR noted difficulty in compiling flow data, for which they need additional TA. Also, the setting up of an integrated monetary database (IMD) is still pending. The authorities reported problems in the integration of the microfinance and the rest of the financial sectors into the monetary sector, and in the electronic treatment of the data. Some data, such as the daily situation of the central bank, are still treated manually. The main priorities for TA should be the identification of flow data and their compilation, the implementation of the IMD, and the integration of microfinance and other financial corporations (e.g., insurance) into the monetary statistics.

70. Several TA recommendations in BOP statistics from the June 2003 multisector mission and a subsequent mission during May 23-June 12, 2007 have not been entirely implemented. For example, the use of the balance of settlement classification as a first step toward the adoption of the BPM5 has not been achieved. Currently, the presentation of BOP using BPM5 is done only for the data sent to the IMF. The BPM4 presentation continues to be used for the NBR publications. Also, the treatment and production of external trade statistics for all products have not been entirely transferred to the Rwanda Revenue Authority (RRA). Such is the case for coffee and tea, for which the NBR still collects the data from customs declaration contracts. Finally, collaboration has not yet begun with the Central Public Investment and External Finance Bureau (CEPEX) for the collection of exhaustive data on international bilateral aid broken down by current and capital transfers.

\section{Strengthening of institutional capacity}

\section{To strengthen the NSS, TA should focus on enhancing the capacity of the NISR} and MINECOFIN. Such efforts need to be coordinated and supported by other TA and resource providers. Real sector statistics and GFS are the major priorities for future TA.

72. Improving real sector statistics constitute the major priority of the NSS. The needs in this sector include (i) strengthening the NISR's human and financial capacity to ensure the sustainability of statistical production; (ii) estimating quarterly GDP;

(iii) finalizing the ongoing work to rebase the PPI on the manufacturing sector activities, which will include mining and quarrying, electricity, gas, and water and publish on a monthly basis; (iv) compiling a quantity and volume industrial production index; and (v) compiling a price and production index for the construction industry and a service sector index. There is also a need to have the NISR take full responsibility for the CPI and PPI in order to promote the transparency of the NBR in conducting monetary policy, among other things, to stabilize prices. 
73. Further TA in GFS should be aimed at improving the existing classification of financial statistics to comply with the Government Finance Statistics Manual 2001 (GFSM 2001), and to develop a strategic plan to move toward GFSM 2001. Success in reaching these objectives would be measured by the ability of MINECOFIN to prepare and present the 2009/10 budget using the revised classification. Another criterion to evaluate success would be the regular dissemination of statistical information, starting in July 2009. Importantly, these reforms need to be closely integrated with the ongoing PFM reforms to ensure that the country and TA providers realize the synergies inherent in such a coordinated approach. The authorities also believe that future TA will enhance staff capacity through learning by doing. ${ }^{15}$ In addition, the strategic plan to move toward adopting the GFSM 2001 should contain some milestones that would work as a "performance contract" to encourage the authorities, and staff in particular, to meet their specific objectives. The establishment of a unit dedicated to the compilation and dissemination of GFS would help to target and eventually improve the absorption of TA.

74. TA in MFS should be geared toward full implementation of the MFSM, including the compilation of flow data. In addition, emphasis should be placed on further expanding the coverage of data by integrating microfinance and other financial corporations (e.g., insurance) into the MFS and implementing the IMD to meet the needs of different partners.

75. The authorities have identified a set of priorities for future TA in BOP. These priorities include (i) improving the components that are currently estimated; (ii) making the settlement balance a tool to effectively complement the BOP; and (iii) ensuring the construction of the capital account on reliable data consistent with the state budget. To meet these priorities, it would be necessary to develop a new methodology to improve data collection and train data collectors and compilers. Future TA could help to address these priorities by building on the current system and by taking users' needs into account. In addition, each BOP component should be reviewed to ensure that it is treated according to the methodology of the BPM5.

\section{Risks to the program}

76. National accounts statistics still present a considerable challenge for macroeconomic statistics. One reason for this is that the NISR has only been in existence since 2006. In addition, it has taken on too many responsibilities requiring sizable human and financial resources, without fully anticipating and costing them to establish the funding

\footnotetext{
${ }^{15}$ In October 2008, MINECOFIN sent staff to participate in a DFID-financed GDDS training workshop in GFS in Nairobi.
} 
constraints. Donors expressed concerns that managerial capacity was limited at the NISR and that there may not yet be a clear signal on how the reforms in the Statistical Strategic Plan were going to be costed, prioritized, and funded in the MTEF of the EDPRS. With respect to human resources, the NISR currently employs 33 staff. Effective March 2008, average salaries were increased by about 30 percent. Moreover, 36 additional staff will be recruited in the near future at both headquarters and district levels. ${ }^{16}$ The new staff will need new offices, computers, and training to become fully operational. Staff retention could also be a problem if the compensation package is not as attractive as that of other government institutions, such as the NBR or MINECOFIN.

\section{Inadequate coordination at various levels remains an important risk to the}

program. Hitherto, limited resources at the NISR have hampered its coordinating role, including in utilizing the GDDS framework (with regular updates of metadata and plans for improvement) to prioritize reforms. At the same time, there remains considerable scope for data producers to work closely with data users to enhance the quality and dissemination of data. Within the MINECOFIN, there is scope to integrate the PFM and GFS reforms in order to realize their full potential benefits.

\section{Rwanda's statistical development relies heavily on external financing-} particularly the donor basket budget. This creates the risk that, absent these funds, statistical development would become unsustainable. Too much reliance on donors would relegate the government to a secondary role in funding statistical activities. In this context, there is a risk concerning the timely completion of the NSDS and its integration into the EDPRS and its related MTEF. Achieving these objectives is important to facilitate and coordinate both national and donor medium-term funding of reforms.

\section{Data reporting to STA}

79. Data reporting to STA has been inadequate. Reporting is done mainly through Excel. A few data categories are not reported, including bilateral trade and monetary aggregates. GFS were last reported in 2004, and the Government Finance Statistics Yearbook questionnaire in 1992. Although a few contact persons are registered for the ICS, Rwanda makes very little use of it for reporting. During the past two years, only two submissions through the ICS were made. This list of STA official correspondents for Rwanda was updated during the mission.

\footnotetext{
${ }^{16}$ Subsequent to the TA evaluation mission, the NISR hired 10 staff who participated in a joint East AFRITAC/UNDP training workshop.
} 


\section{Opinion of data users}

80. Despite recent improvements, representatives of the banking industry in Rwanda noted weaknesses in data dissemination. For example, no contact points are indicated on the NBR's website, hyperlinks sometimes do not function, and some data, such as those on loan classification, are disseminated with significant lags (six months). In addition, the banks complained that the NBR seemed to impose heavy data-reporting burdens by requesting them to report every transaction individually.

81. Because the needs of the banks vary according to their purpose, the banks would like the NBR to disseminate the data categories that are of interest to them. For example, some banks are more interested in regional data since they operate in each region, while others are more interested in data on rural areas, such as data on agriculture. The bank representatives noted that the lack of sectoral breakdown made planning difficult. They observed that MINECOFIN's data are available with a lag and their quality could be improved.

82. A second group of users, constituting the rest of the private sector, reported being relatively satisfied with their relationship with the NISR, MINECOFIN, and the NBR. However, they made several suggestions to improve statistics, including (i) updating agencies' websites; (ii) centralizing statistical production and harmonizing the data; (iii) strengthening cooperation between the private sector and government agencies; and (iv) improving sharing of statistical information. This group is also concerned about the lack of sociodemographic and labor market data, and the fact that there might not be an adequate transfer of knowledge to the local staff because most statistical work is done by consultants. They suggested that the government invest more in private sector-specific data, and that the central bank produce more high-frequency data.

83. Some data users felt that Rwanda could take advantage of the experience of neighboring countries to develop its statistical system. Some countries that belong to East AFRITAC are more advanced then Rwanda. Rwanda could therefore benefit by learning from them during regional or bilateral meetings or seminars.

\section{Conclusion}

This evaluation of the TA provided to post-conflict Mozambique and Rwanda points to some success in improving statistical capacity. Nevertheless, much remains to be done as would be expected with long-term efforts to undertake institutional capacity building, particularly against the background of severe conflicts that had weakened TA absorption. The key emerging lessons, which are critical to the provision, absorption, and sustainability of TA, include: 
- Weak institutions make it difficult for post-conflict countries to absorb TA in the initial stages. Initially, TA should focus on diagnostic work and ad hoc efforts for gap-filling to generate rudimentary data. Subsequently, it should focus on establishing a basis to absorb and use TA more effectively. Importantly, TA should be viewed as a medium-to-long-term effort, requiring extensive coordination with donors and focusing on rebuilding institutional capacity, especially in the NSOs;

- the vital role of commitment to, and ownership of, TA by the country authorities;

- the importance of statistical legal and institutional frameworks, especially with regard to national statistical organizations;

- the central role of adequate resources, including stable staff to serve as counterparts to IMF staff and experts in facilitating the transfer and retention of knowledge;

- $\quad$ the need to emphasize prioritizing reforms and linking them to the budget. For developing countries, and especially post-conflict countries, mainstreaming of statistics in the national priorities and the funding of related reforms within the PRSPs and supporting MTEFs facilitate access to medium-term funding and the ability to undertake and continue with the reform process;

- the importance of effective coordination with donors, other Fund departments, and regional organizations, such as the AFRITACs, in permitting flexibility in supporting a broader set of interlinked reforms;

- the value of the GDDS framework in assisting the countries to coordinate better in documenting and updating progress, while prioritizing reforms and TA;

- the significance of addressing the language constraint that may otherwise hamper the effectiveness of TA;

- the importance for STA of the expert selection and the mix of TA delivery. 


\section{Appendix Table 1. Mozambique: TA Missions Delivered by STA During 2000-08}

\begin{tabular}{|c|c|c|c|c|}
\hline No. & Topic & Dates & Duration & Funding 1/ \\
\hline \multicolumn{5}{|c|}{ GDDS and national accounts } \\
\hline 1 & GDDS and national accounts peripatetic advisor & Aug. 2002-Dec. 20, 2003 & $\begin{array}{l}\text { One year and } \\
\text { four months }\end{array}$ & JSA / Expert \\
\hline 2 & GDDS and national accounts peripatetic advisor & Jan.21-Mar. 25, 2003 & 4.5 weeks & JSA / Expert \\
\hline 3 & GDDS and national accounts peripatetic advisor & Apr. 10-June 10, 2003 & 8 weeks & JSA / Expert \\
\hline 4 & GDDS and national accounts peripatetic advisor & Aug. 12-Sep. 28, 2003 & 6 weeks & JSA / Expert \\
\hline 5 & GDDS and national accounts peripatetic advisor & Oct. 13-Nov. 1, 2003 & 2 weeks & JSA / Expert \\
\hline 6 & GDDS and national accounts peripatetic advisor & Nov. 16, 2003-Jan. 5, 2004 & 3.5 weeks & JSA / Expert \\
\hline 7 & GDDS and national accounts peripatetic advisor & Jan. 27-Mar. 13, 2004 & 3 weeks & JSA / Expert \\
\hline 8 & GDDS and national accounts peripatetic advisor & Mar. 21-Apr. 25, 2004 & 4 weeks & JSA / Expert \\
\hline 9 & GDDS and national accounts peripatetic advisor & May 8-June 20, 2004 & 5 weeks & JSA / Expert \\
\hline 10 & GDDS and national accounts peripatetic advisor & July 3-Aug. 11, 2004 & 5 weeks & JSA / Expert \\
\hline 11 & GDDS and national accounts peripatetic advisor & Aug. 12-Nov. 23, 2004 & 24 weeks & JSA / Expert \\
\hline 12 & GDDS and national accounts peripatetic advisor & Dec. 08, 2004-Jan. 7, 2005 & 4 weeks & JSA / Expert \\
\hline 13 & GDDS and national accounts peripatetic advisor & Jan. 24-Feb. 17, 2005 & 2 weeks & JSA / Expert \\
\hline 14 & GDDS and national accounts peripatetic advisor & Mar. 12-28, 2005 & 2 weeks & JSA / Expert \\
\hline 15 & GDDS and national accounts peripatetic advisor & Mar. 28-Apr. 1, 2005 & 2 weeks & JSA / Expert \\
\hline 16 & National accounts peripatetic advisor & Apr. 24-Aug. 11, 2005 & 27 weeks & JSA / Expert \\
\hline 17 & National accounts advisor & Aug. 2005-Aug. 2006 & One year & JSA / Expert \\
\hline 18 & National accounts mission & Mar. 26-Apr. 11, 2008 & 2.5 weeks & STA/ Expert \\
\hline \multicolumn{5}{|c|}{ Price statistics } \\
\hline 1 & Consumer price statistics mission & May $17-28,2004$ & 2 weeks & JSA / Expert \\
\hline 2 & Consumer price statistics mission & June 27-July 8, 2005 & 2 weeks & JSA / Expert \\
\hline 3 & Consumer price statistics mission & June 21-July 11, 2006 & 2 weeks & STA/ Expert \\
\hline \multicolumn{5}{|c|}{ Balance of payments statistics } \\
\hline 1 & Balance of payments statistics peripatetic advisor & Jan. 15-Apr. 13, 2001 & 3 months & STA / Expert \\
\hline 2 & Balance of payments statistics peripatetic advisor & June $17-$ Oct. 09, 2002 & 3 months & STA / Expert \\
\hline 3 & Balance of payments statistics mission & July $28-$ Aug. 13, 2003 & 2 weeks & JSA / Expert \\
\hline 4 & Balance of payments statistics mission & May 5-19, 2004 & 2 weeks & JSA / Expert \\
\hline 5 & Balance of payments statistics mission & Nov. 24-Dec. 8, 2004 & 2 weeks & JSA / Expert \\
\hline 6 & Balance of payments statistics mission & May $17-30,2005$ & 2 weeks & JSA / Expert \\
\hline 7 & Balance of payments statistics mission & Jan. 28-Feb. 8, 2008 & 2 weeks & DFID/ Expert \\
\hline \multicolumn{5}{|c|}{ Monetary and financial statistics } \\
\hline 1 & Monetary and financial statistics mission & Jan. 8-23, 2000 & 2 weeks & STA/ Staff \\
\hline 2 & Monetary and financial statistics mission & Sep. $15-30,2004$ & 2 weeks & STA/ Staff \\
\hline 3 & Monetary and financial statistics mission & Nov. 7-21, 2007 & 2 weeks & STA/ Staff \\
\hline \multicolumn{5}{|c|}{ Government finance statistics } \\
\hline 1 & Government finance statistics mission & May $1-16,2003$ & 2 weeks & JSA / Expert \\
\hline 2 & Government finance statistics mission & July $18-29,2005$ & 2 weeks & JSA / Expert \\
\hline
\end{tabular}

1/ Japan Administered Account for Selected Fund Activities (JSA), under JSA-financed Lusophone Africa GDDS Project (Phases I to III). DFID, under DFID-financed Anglophone Project (Phase III). 


\section{Appendix Table 2. Mozambique: Participants in IMF Training Courses During 2003-08}

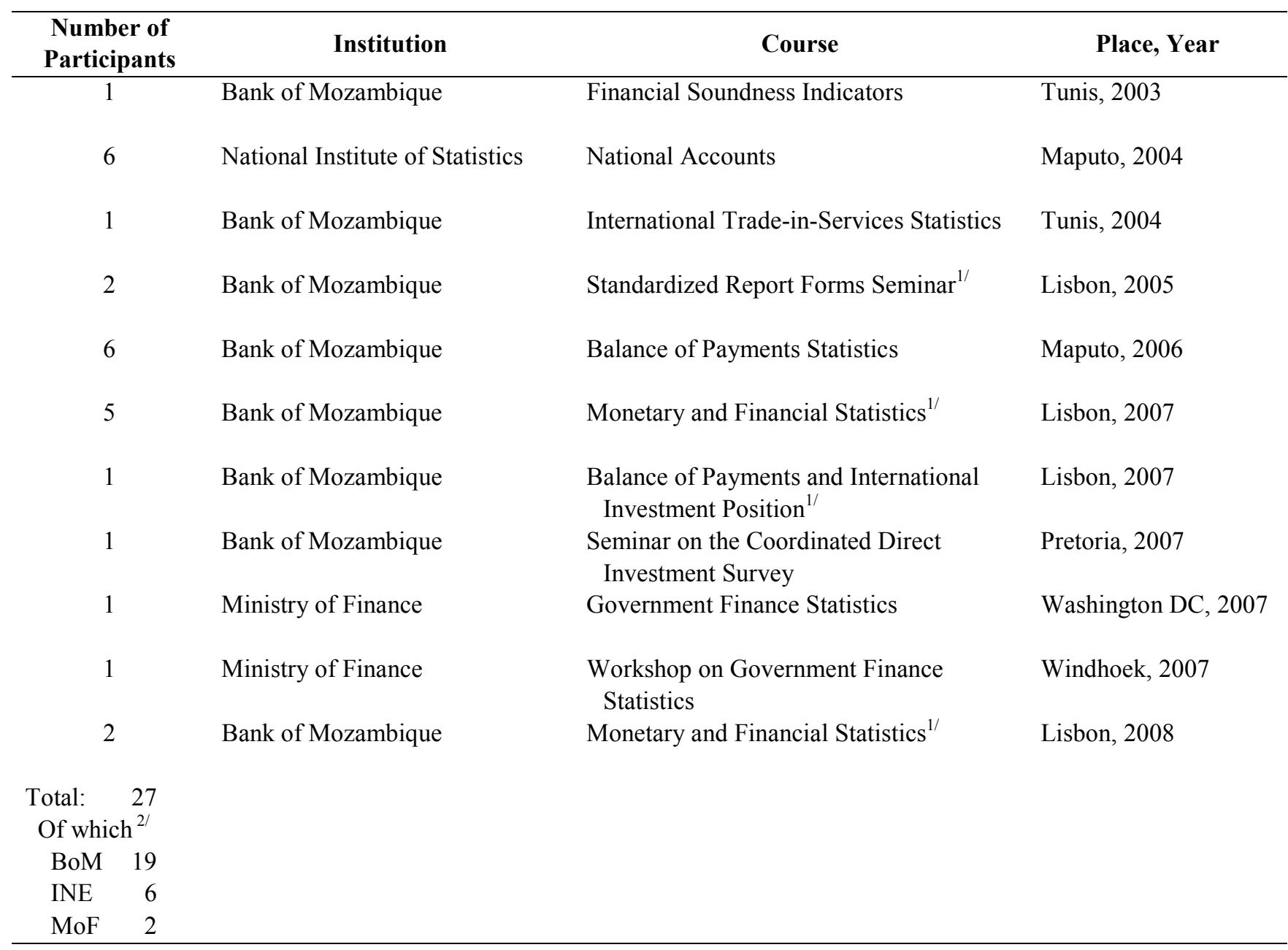

${ }^{1 /}$ In collaboration with the Bank of Portugal (BoP).

${ }^{2 /}$ Bank of Mozambique (BoM), Instituto Nacional de Estatistica (INE), and Ministry of Finance (MoF). 
Appendix Table 3. Mozambique: Authorities' Views on STA's Technical Assistance

\begin{tabular}{|c|c|c|c|c|}
\hline & 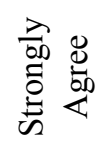 & 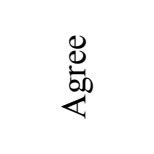 & $\begin{array}{l}\bar{\pi} \\
\text { 苛 } \\
Z\end{array}$ & 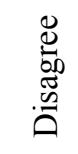 \\
\hline Areas of technical assistance work responded to your priority need. & $\begin{array}{l}\text { BOP, } \\
\text { MFS }\end{array}$ & $\begin{array}{l}\text { NA, } \\
\text { CPI, } \\
\text { GFS }\end{array}$ & & \\
\hline $\begin{array}{l}\text { Recommendations of the mission(s) and time frame for implementation (e.g., action } \\
\text { plan) were discussed and agreed with the authorities. }\end{array}$ & $\begin{array}{l}\text { CPI } \\
\text { MFS }\end{array}$ & $\begin{array}{l}\text { NA, } \\
\text { BOP, } \\
\text { GFS }\end{array}$ & & \\
\hline The structure, length, and content of mission reports are appropriate for your needs. & $\begin{array}{l}\text { CPI, } \\
\text { MFS }\end{array}$ & $\begin{array}{l}\text { BOP, } \\
\text { GFS }\end{array}$ & NA & \\
\hline $\begin{array}{l}\text { Technical assistance mission(s) provided applied, hands-on training in areas being } \\
\text { addressed. }\end{array}$ & MFS & $\begin{array}{l}\text { BOP, } \\
\text { NA, CPI }\end{array}$ & & GFS \\
\hline $\begin{array}{l}\text { Technical assistance facilitated your country's participation in GDDS and/or progress } \\
\text { toward subscription to SDDS. }\end{array}$ & $\begin{array}{l}\text { NA, } \\
\text { CPI }\end{array}$ & $\begin{array}{l}\text { BOP, } \\
\text { MFS }\end{array}$ & GFS & \\
\hline Technical assistance facilitated your policy analysis, formulation, and monitoring. & MFS & $\begin{array}{c}\text { BOP, } \\
\text { CPI, } \\
\text { MFS, } \\
\text { GFS }\end{array}$ & NA & \\
\hline $\begin{array}{l}\text { Technical assistance facilitated the dissemination (publication) of more and better- } \\
\text { quality statistics. }\end{array}$ & $\begin{array}{l}\text { CPI, } \\
\text { MFS }\end{array}$ & $\begin{array}{l}\text { BOP, } \\
\text { NA }\end{array}$ & GFS & \\
\hline Technical assistance resulted in improved data dissemination practices. & CPI & $\begin{array}{l}\text { BOP } \\
\text { NA, } \\
\text { MFS }\end{array}$ & GFS & \\
\hline Technical assistance facilitated regular data provision to IMF area departments. & MFS & BOP & $\begin{array}{l}\text { NA, } \\
\text { GFS }\end{array}$ & \\
\hline Technical assistance facilitated regular data provision for publication in IFS. & MFS & BOP & $\begin{array}{l}\text { NA, } \\
\text { GFS }\end{array}$ & \\
\hline $\begin{array}{l}\text { Technical assistance facilitated coordination among national authorities and interaction } \\
\text { with other donors. }\end{array}$ & NA & $\begin{array}{l}\text { BOP, } \\
\text { MFS }\end{array}$ & GFS & \\
\hline
\end{tabular}

\begin{tabular}{ll}
\hline & Mozambique: Usefulness of Technical Assistance Missions \\
\hline Very useful & NA, MFS, BOP, CPI \\
Mostly useful & GFS \\
Somewhat useful & \\
Hardly useful & \\
\hline
\end{tabular}

\begin{tabular}{ll}
\hline \multicolumn{2}{c}{ Mozambique: Delivery Mode that Better Meets the Country’s Technical Assistance Needs } \\
\hline Mission / short-term visit (two weeks) & CPI, BOP, MFS \\
Training / workshops (IMF headquarters and regional centers) & GFS \\
Resident/ peripatetic expert & NA \\
Other &
\end{tabular}

National accounts statistics (NA); consumer price index statistics (CPI); balance of payments statistics (BOP); and monetary and financial statistics (MFS). 


\section{Appendix Table 4. Mozambique: Overview of Current Practices Regarding Coverage, Periodicity, and Timeliness of Data Compared with the GDDS}

\begin{tabular}{|c|c|c|c|c|c|}
\hline \multirow{2}{*}{ GDDS Data Category } & \multirow{2}{*}{$\begin{array}{l}\text { Coverage } \\
\text { (Meets } \\
\text { GDDS) } \\
\end{array}$} & \multicolumn{2}{|c|}{ Periodicity } & \multicolumn{2}{|c|}{ Timeliness } \\
\hline & & GDDS & Mozambique & GDDS & Mozambique \\
\hline \multicolumn{6}{|c|}{ COMPREHENSIVE FRAMEWORK } \\
\hline Real sector: National accounts & Yes & $\mathrm{A}$ & $\mathrm{A}$ & $10-14 \mathrm{M}$ & $\begin{array}{l}\text { Prelim: } 6 \mathrm{M} \\
\text { Final: } 24 \mathrm{M}\end{array}$ \\
\hline Fiscal sector: Central govt. operations & $\mathrm{Yes}^{2}$ & A & A & $6-9 \mathrm{M}$ & $18 \mathrm{M}$ \\
\hline General govt. operations & $Y_{e s}^{2}$ & $A$ & $A$ & $6-9 M$ & $18 \mathrm{M}$ \\
\hline Central govt. debt & Yes & A & A & $6-9 \mathrm{M}$ & $18 \mathrm{M}$ \\
\hline Financial sector: Broad money survey & Yes & M & M & $2-3 \mathrm{M}$ & $1 \mathrm{M}$ \\
\hline External sector: Balance of payments & Yes & A & $\mathrm{Q}, \mathrm{A}$ & $6-9 \mathrm{M}$ & Q, A: $3 \mathrm{M}$ \\
\hline International investment position & Yes $^{2}$ & A & A & $6-9 \mathrm{M}$ & $12 \mathrm{M}$ \\
\hline \multicolumn{6}{|c|}{ DATA CATEGORIES AND INDICATORS } \\
\hline \multicolumn{6}{|l|}{ Real sector } \\
\hline GDP (nominal and real) & Yes & $\mathrm{A}(Q)$, & $\mathrm{A}, \mathrm{Q}$ & $6-9 \mathrm{M}$ & $\begin{array}{l}\text { Prelim: } 6 \mathrm{M} \\
\text { Final: } 24 \mathrm{M}\end{array}$ \\
\hline $\begin{array}{l}\text { Gross national income, capital formation, } \\
\text { saving }\end{array}$ & & $\mathrm{A}(Q)$ & & & \\
\hline $\begin{array}{l}\text { Manufacturing or industrial production } \\
\text { index/indices. }\end{array}$ & Yes & M & Q & $6-12 \mathrm{~W}$ & $45 \mathrm{D}$ \\
\hline $\begin{array}{l}\text { Primary commodity, agricultural, or other } \\
\text { indices, as relevant }\end{array}$ & Yes & $\begin{array}{l}\text { As } \\
\text { relevant }\end{array}$ & $\mathrm{Q}, \mathrm{A}$ & $3 \mathrm{M}$ & $\begin{array}{l}\text { Q: } 45 \mathrm{D} \\
\text { A: } 45-50 \mathrm{D}\end{array}$ \\
\hline Consumer price index & Yes & M & M & $1-2 \mathrm{M}$ & Up to $10 \mathrm{D}$ \\
\hline Producer price index & No & $M$ & $\ldots$ & $1-2 \mathrm{M}$ & $\ldots$ \\
\hline Employment & $\mathrm{Yes}^{3}$ & A & A & $6-9 \mathrm{M}$ & $6 \mathrm{M}$ \\
\hline Unemployment & $\mathrm{Yes}^{3}$ & A & A & $6-9 \mathrm{M}$ & $6 \mathrm{M}$ \\
\hline Wages/earnings (all sectors) & $\mathrm{Yes}^{4}$ & A & Q & $6-9 \mathrm{M}$ & $6 \mathrm{M}$ \\
\hline \multicolumn{6}{|l|}{ Fiscal sector } \\
\hline $\begin{array}{l}\text { Central govt. aggregates: revenue, } \\
\text { expenditure, balance, and financing with } \\
\text { breakdowns (debt holder, instrument, } \\
\text { currency), as relevant }\end{array}$ & Yes $^{2}$ & Q & Q & $1 \mathrm{Q}$ & $45 \mathrm{D}$ \\
\hline Interest payments & $Y_{e s}^{2}$ & $Q$ & $Q$ & $1 \mathrm{Q}$ & $45 \mathrm{D}$ \\
\hline $\begin{array}{l}\text { Central govt. debt: domestic and foreign debt, } \\
\text { with appropriate breakdowns (debt holder, } \\
\text { instrument, maturity, currency), as relevant }\end{array}$ & Yes & $\mathrm{A}(Q)$ & A & $1-2 \mathrm{Q}$ & $3 \mathrm{Q}$ \\
\hline Government-guaranteed debt & $N A$ & $A(Q)$ & $N A$ & $1-2 \mathrm{Q}$ & $N A$ \\
\hline \multicolumn{6}{|l|}{ Financial sector } \\
\hline $\begin{array}{l}\text { Broad money and credit aggregates: net } \\
\text { external position, domestic credit, broad or } \\
\text { narrow money }\end{array}$ & Yes & $\mathrm{M}$ & $\mathrm{M}$ & $1-3 \mathrm{M}$ & $1 \mathrm{M}$ \\
\hline Central bank aggregates: monetary base & Yes & M & M & $1-2 \mathrm{M}$ & $1 \mathrm{M}$ \\
\hline $\begin{array}{l}\text { Interest rates: short- and long-term govt. } \\
\text { security rates, policy variable rate }\end{array}$ & Yes & M & M & $\begin{array}{l}\text { High-frequency } \\
\text { publication }\end{array}$ & Daily on BOM website \\
\hline $\begin{array}{l}\text { Money or interbank market rates and a range } \\
\text { of deposit and lending rates }\end{array}$ & Yes & $M$ & $D$ & $\begin{array}{l}\text { High-frequency } \\
\text { publication }\end{array}$ & $\begin{array}{l}\text { Same day in the } \\
\text { newspaper }\end{array}$ \\
\hline Stock market: share price index, as relevant & $N A$ & $M$ & $N A$ & $\begin{array}{l}\text { High-frequency } \\
\text { publication }\end{array}$ & $N A$ \\
\hline \multicolumn{6}{|l|}{ External sector } \\
\hline $\begin{array}{l}\text { Balance of payments aggregates: imports and } \\
\text { exports of goods and services, current } \\
\text { account balance, reserves }\end{array}$ & Yes & $\mathrm{A}(\mathrm{Q})$ & $\mathrm{A}, \mathrm{Q}$ & $6 \mathrm{M}$ & A, Q: $3 \mathrm{M}$ \\
\hline
\end{tabular}




\section{Appendix Table 4. Mozambique: Overview of Current Practices Regarding Coverage, Periodicity, and Timeliness of Data Compared with the GDDS ${ }^{1}$ (concluded)}

\begin{tabular}{|c|c|c|c|c|c|}
\hline \multirow{2}{*}{ GDDS Data Category } & \multirow{2}{*}{$\begin{array}{l}\text { Coverage } \\
\text { (Meets } \\
\text { GDDS) }\end{array}$} & \multicolumn{2}{|c|}{ Periodicity } & \multicolumn{2}{|c|}{ Timeliness } \\
\hline & & GDDS & Mozambique & GDDS & Mozambique \\
\hline $\begin{array}{l}\text { Public and publicly guaranteed external debt } \\
\text { outstanding, with maturity breakdown }\end{array}$ & No & Q & -- & $1-2 \mathrm{Q}$ & -- \\
\hline $\begin{array}{l}\text { Public and publicly guaranteed external debt- } \\
\text { service schedule }^{5}\end{array}$ & No & $\begin{array}{l}\text { Twice } \\
\text { yearly }\end{array}$ & -- & $3-6 \mathrm{M}$ & -- \\
\hline $\begin{array}{l}\text { Private external debt not publicly guaranteed } \\
\text { and debt-service schedule }\end{array}$ & No & $A$ & -- & $6-9 \mathrm{M}$ & -- \\
\hline $\begin{array}{l}\text { International reserves: gross official reserves } \\
\text { denominated in U.S. dollars }\end{array}$ & Yes & M & M & $1-4 \mathrm{~W}$ & $4 \mathrm{~W}$ \\
\hline Reserve-related liabilities & Yes & $M$ & $M$ & $1-4 \mathrm{~W}$ & $4 \mathrm{~W}$ \\
\hline $\begin{array}{l}\text { Merchandise trade: total exports and total } \\
\text { imports }\end{array}$ & Yes & M & Q & $8-12 \mathrm{~W}$ & $3 \mathrm{M}$ \\
\hline $\begin{array}{l}\text { Major commodity breakdowns with longer } \\
\text { time lapse }\end{array}$ & Yes & $M$ & $A, Q$ & $8-12 \mathrm{M}$ & $3 \mathrm{M}$ \\
\hline Exchange rates: spot rates & Yes & $\mathrm{D}$ & $\mathrm{D}$ & $\begin{array}{l}\text { High-frequency } \\
\text { publication }\end{array}$ & $\begin{array}{l}\text { Same day in the } \\
\text { newspapers }\end{array}$ \\
\hline $\begin{array}{l}\text { Population: population characteristics and } \\
\text { dynamics of growth; indicators related to } \\
\text { Millennium Development Goals (MDGs) }\end{array}$ & $\mathrm{Yes}^{6}$ & $\begin{array}{c}\text { A } \\
\text { Census } \\
\text { every } \\
\text { ten } \\
\text { years }\end{array}$ & A & $\begin{array}{c}\text { 3-6 } \mathrm{M} \text { for annual } \\
\text { updates } \\
\text { 9-12 } \mathrm{M} \text { for } \\
\text { Census }\end{array}$ & $\begin{array}{c}3-6 \mathrm{M} \\
9-12 \mathrm{M}\end{array}$ \\
\hline $\begin{array}{l}\text { Disaggregation by age, sex and region as } \\
\text { appropriate; mortality rates, crude birth } \\
\text { rate, fertility rate and life expectancy }\end{array}$ & $Y_{e s}^{6}$ & $A$ & A & $\begin{array}{c}\text { 3-6 M for } \\
\text { annual updates } \\
\text { 9-12 M for } \\
\text { Census }\end{array}$ & $6-12 \mathrm{M}$ \\
\hline $\begin{array}{l}\text { Education: inputs, measures and outcomes; } \\
\text { indicators related to MDGs }\end{array}$ & Yes $^{6}$ & A & A & $6-12 \mathrm{M}$ & $12 \mathrm{M}$ \\
\hline $\begin{array}{l}\text { Disaggregation by region, characteristics of } \\
\text { teaching staff, expenditures, net enrollment } \\
\text { rates, outcomes by age and sex }\end{array}$ & Yes $^{6}$ & A & A & $6-12 \mathrm{M}$ & $12 \mathrm{M}$ \\
\hline $\begin{array}{l}\text { Health: inputs and process (service delivery), } \\
\text { number of clients served, type of care, } \\
\text { immunizations; indicators related to MDGs }\end{array}$ & Yes $^{6}$ & A & A & $3-6 \mathrm{M}$ & $6 \mathrm{M}$ \\
\hline $\begin{array}{l}\text { Household expenditures on heath services, } \\
\text { data by region, measures of responsiveness }\end{array}$ & Yes $^{6}$ & A & A & $3-6 \mathrm{M}$ & $6 \mathrm{M}$ \\
\hline
\end{tabular}

Notes: Key to symbols: $\mathrm{A}=$ annual; $\mathrm{D}=$ daily; $\mathrm{M}=$ monthly; $\mathrm{Q}=$ quarterly; $\mathrm{NA}=$ not applicable.

1. Italics indicate encouraged categories.

2. Coverage not comprehensive.

3. Estimates based on household surveys with restricted samples, which do not permit compilation of unemployment data.

4. From a sample of establishments. Index numbers and average wages for manufacturing, construction, and some services.

5. The BoM disseminates public external debt by creditor but not by maturity. Data on maturity are compiled but not disseminated.

The BoM compiles a public debt-service schedule but does not disseminate it. There is no publicly guaranteed debt.

6. Data on all basic components and encouraged extensions are not available. 


\section{Appendix Table 5. Rwanda: STA, East AFRITAC, and DFID TA Missions Delivered During 2000-08}

\begin{tabular}{|c|c|c|c|c|}
\hline No. & Topic & Dates & Duration & Source of TA \\
\hline \multicolumn{5}{|c|}{ National accounts } \\
\hline 1 & National accounts & Oct. 1-5, 2007 & 5 days & East AFRITAC \\
\hline 2 & $\begin{array}{l}\text { National accounts } \\
\text { (training) }\end{array}$ & Oct. $1-5,2007$ & 5 days & East AFRITAC \\
\hline 3 & National accounts & Jul. 17-28, 2006 & 12 days & East AFRITAC \\
\hline \multicolumn{5}{|c|}{ Price statistics * } \\
\hline & Consumer price index & & & DFID \\
\hline 1 & Producer price index & Feb. 23-Mar. 5, 2003 & 11 days & East AFRITAC \\
\hline 2 & Producer price index & Jan. 27-Feb. 7, 2004 & 12 days & East AFRITAC \\
\hline 3 & Producer price index & Jul. 26-Aug.6, 2004 & 12 days & East AFRITAC \\
\hline 4 & Producer price index & May $17-26,2005$ & 10 days & East AFRITAC \\
\hline \multicolumn{5}{|c|}{ Balance of payments statistics } \\
\hline 1 & $\begin{array}{l}\text { Balance of payments } \\
\text { statistics }\end{array}$ & May 23-Jun. 15, 2007 & 3 weeks & East AFRITAC \\
\hline 2 & $\begin{array}{l}\text { Balance of payments } \\
\text { statistics }\end{array}$ & Sep. 27-Oct.10, 2006 & 2 weeks & East AFRITAC \\
\hline 3 & $\begin{array}{l}\text { Balance of payments } \\
\text { statistics }\end{array}$ & Jun. 14-27, 2005 & 2 weeks & STA \\
\hline 4 & $\begin{array}{l}\text { Balance of payments } \\
\text { statistics }\end{array}$ & Jan. 7-Feb. 6, 2004 & 4 weeks & STA \\
\hline 5 & $\begin{array}{l}\text { Balance of payments } \\
\text { statistics }\end{array}$ & Jun. 18-Jul. 11, 2003 & 24 days & STA \\
\hline 6 & $\begin{array}{l}\text { Balance of payments } \\
\text { statistics }\end{array}$ & Sep. 26-Oct. 7, 2000 & 12 days & STA \\
\hline \multicolumn{5}{|c|}{ Monetary and financial statistics } \\
\hline 1 & $\begin{array}{l}\text { Money and banking } \\
\text { statistics }\end{array}$ & Nov. $15-28,2000$ & 2 weeks & STA \\
\hline 2 & $\begin{array}{l}\text { Money and banking } \\
\text { statistics }\end{array}$ & Aug. 8-21, 2007 & 2 weeks & STA \\
\hline \multicolumn{5}{|c|}{ Government finance statistics } \\
\hline 1 & $\begin{array}{l}\text { Government finance } \\
\text { statistics }^{1 /}\end{array}$ & May 5-16, 2008 & 12 days & East AFRITAC \\
\hline 2 & $\begin{array}{l}\text { Government finance } \\
\text { statistics }\end{array}$ & Jan. 7-16, 2004 & 10 days & East AFRITAC \\
\hline 1 & Multisector statistics & Jun. 25-Jul. 5, 2003 & 11 days & STA \\
\hline
\end{tabular}


Appendix Table 6. Rwanda: Participants in IMF Training Courses During 2000-08

\begin{tabular}{|c|c|c|c|}
\hline $\begin{array}{l}\text { Number of } \\
\text { Participants }\end{array}$ & Institution & Course & Place, Year \\
\hline 4 & National Bank of Rwanda & Monetary and Financial Statistics & Tunis, 2005 \\
\hline 2 & National Bank of Rwanda & Monetary and Financial Statistics & Tunis, 2006 \\
\hline 3 & National Bank of Rwanda & Monetary and Financial Statistics & Tunis, 2007 \\
\hline 1 & National Bank of Rwanda & Monetary and Financial Statistics & Tunis, 2003 \\
\hline 1 & $\begin{array}{l}\text { Ministry of Finance and } \\
\text { Economic Planning }\end{array}$ & Monetary and Financial Statistics & Tunis, 2001 \\
\hline 2 & National Bank of Rwanda & Monetary and Financial Statistics & Abidjan, 2002 \\
\hline 1 & National Bank of Rwanda & Balance of Payments & Washington DC, 2000 \\
\hline 1 & National Bank of Rwanda & Balance of Payments & Washington DC, 2001 \\
\hline 2 & National Bank of Rwanda & Balance of Payments & Abidjan, 2002 \\
\hline 2 & National Bank of Rwanda & Balance of Payments & Tunis, 2004 \\
\hline 2 & National Bank of Rwanda & Balance of Payments & Tunis, 2006 \\
\hline 1 & National Bank of Rwanda & Balance of Payments & Tunis, 2008 \\
\hline 3 & National Bank of Rwanda & $\begin{array}{l}\text { International Investment Position and } \\
\text { External Debt Statistics }\end{array}$ & Munyonyo, 2008 \\
\hline 1 & National Bank of Rwanda & Coordinated Investment Survey Workshop & Tunis, 2008 \\
\hline 4 & National Bank of Rwanda & $\begin{array}{l}\text { Compilation of Financial Soundness } \\
\text { Indicators }\end{array}$ & Nairobi, 2008 \\
\hline 1 & National Bank of Rwanda & Remittances Statistics & Tunis, 2008 \\
\hline 1 & National Bank of Rwanda & International Trade-In Services & Tunis, 2007 \\
\hline 1 & $\begin{array}{l}\text { National Institute of } \\
\text { Statistics of Rwanda }\end{array}$ & International Trade-In-Services & Tunis, 2007 \\
\hline 1 & $\begin{array}{l}\text { Ministry of Finance and } \\
\text { Economic Planning }\end{array}$ & National Accounts & Washington DC, 2002 \\
\hline 1 & $\begin{array}{l}\text { Ministry of Finance and } \\
\text { Economic Planning }\end{array}$ & National Accounts & Washington DC, 2004 \\
\hline 2 & $\begin{array}{l}\text { National Institute of } \\
\text { Statistics of Rwanda }\end{array}$ & National Accounts & Tunis, 2007 \\
\hline 1 & $\begin{array}{l}\text { Ministry of Finance and } \\
\text { Economic Planning }\end{array}$ & Government Finance Statistics & Washington DC, 2000 \\
\hline 1 & $\begin{array}{l}\text { Ministry of Finance and } \\
\text { Economic Planning }\end{array}$ & Government Finance Statistics & Washington DC, 2002 \\
\hline 1 & $\begin{array}{l}\text { Ministry of Finance and } \\
\text { Economic Planning }\end{array}$ & Government Finance Statistics & Washington DC, 2004 \\
\hline 1 & $\begin{array}{l}\text { Ministry of Finance and } \\
\text { Economic Planning }\end{array}$ & Government Finance Statistics & Tunis, 2006 \\
\hline 1 & $\begin{array}{l}\text { National Institute of } \\
\text { Statistics of Rwanda }\end{array}$ & Government Finance Statistics & Tunis, 2006 \\
\hline 2 & $\begin{array}{l}\text { Ministry of Finance and } \\
\text { Economic Planning }\end{array}$ & Government Finance Statistics & Washington DC, 2008 \\
\hline 1 & National Bank of Rwanda & Financial Soundness Indicators & Tunis, 2003 \\
\hline 1 & $\begin{array}{l}\text { Ministry of Finance and } \\
\text { Economic Planning }\end{array}$ & External Debt & Tunis, 2007 \\
\hline \multicolumn{4}{|l|}{$\begin{array}{l}\text { Total: } 46 \\
\text { Of which: } \\
\text { BNR: } 32 \\
\text { MINECOFIN:10 } \\
\text { NISR: } 4\end{array}$} \\
\hline
\end{tabular}


Appendix Table 7. Rwanda: Authorities' Views on STA's Technical Assistance

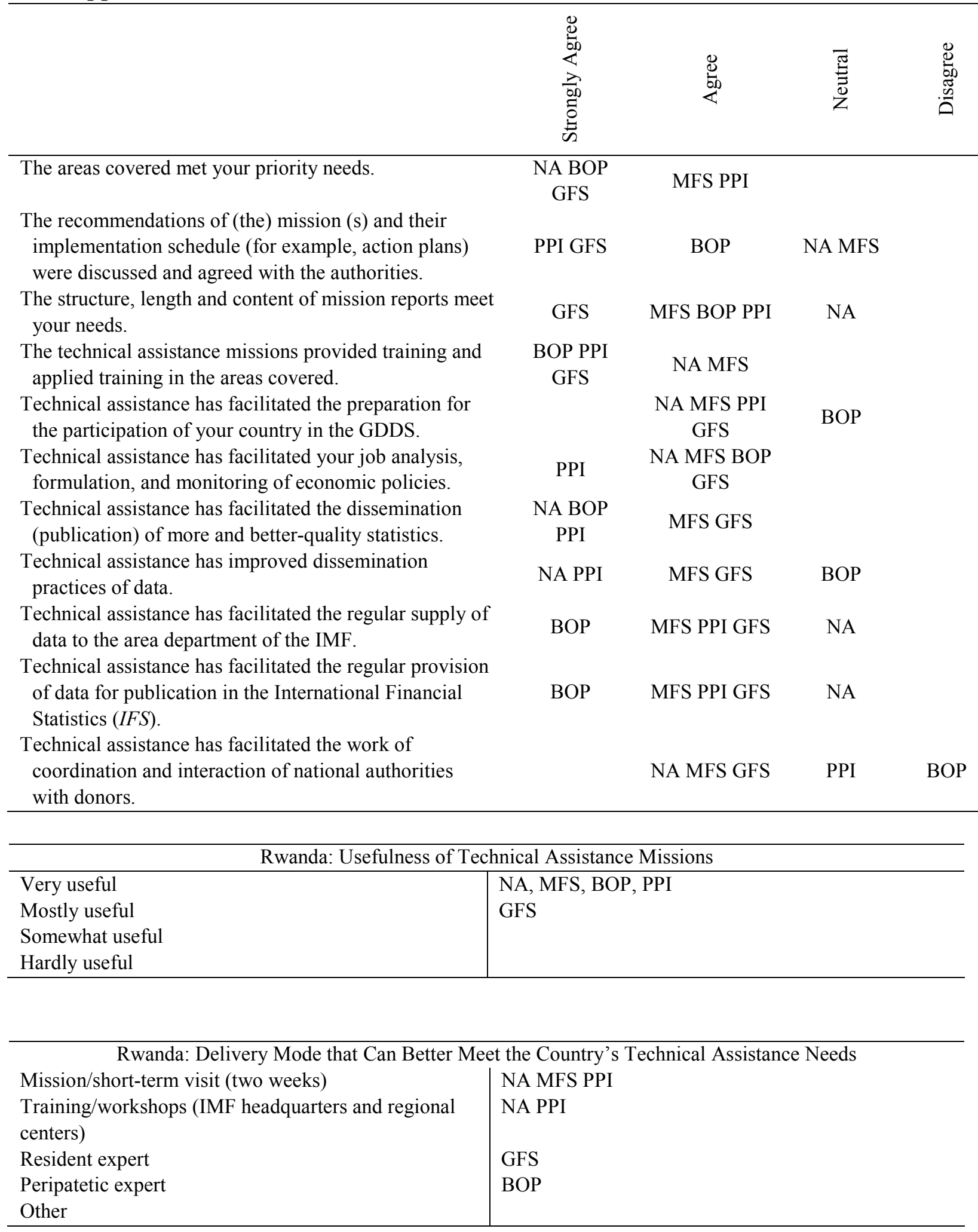

NA: national accounts statistics; PPI: producer price index, GFS: government finance statistics; MFS: monetary and financial statistics; and BOP: balance of payments statistics. 


\section{Appendix Table 8. Rwanda: Overview of Current Practices Regarding Coverage, Periodicity, and Timeliness of Data Compared with the GDDS}

\begin{tabular}{|c|c|c|c|c|c|}
\hline & $\begin{array}{l}\text { Availability } \\
\text { of the Data }\end{array}$ & $\begin{array}{c}\text { GDDS } \\
\text { Periodicity }\end{array}$ & $\begin{array}{c}\text { Rwanda } \\
\text { Periodicity }\end{array}$ & $\begin{array}{c}\text { GDDS } \\
\text { Timeliness }\end{array}$ & $\begin{array}{c}\text { Rwanda } \\
\text { Timeliness }\end{array}$ \\
\hline \multicolumn{6}{|c|}{ COMPREHENSIVE FRAMEWORK } \\
\hline Real sector: national accounts & Yes & $A$ & $A$ & $10-14 M$ & $18 M$ \\
\hline $\begin{array}{l}\text { Fiscal sector: central govt. } \\
\text { operations }\end{array}$ & Yes & $A$ & $M$ & $6-9 M$ & $2 W$ \\
\hline General government. & No & $A$ & $N A$ & $6-9 M$ & $N A$ \\
\hline $\begin{array}{l}\text { operations } \\
\text { Central government debt }\end{array}$ & Yes & $A(Q)$ & $M$ & $6-9 M$ & $\begin{array}{l}\text { Within one month } \\
\text { after the end of } \\
\text { the reference } \\
\text { period. }\end{array}$ \\
\hline $\begin{array}{l}\text { Financial sector: depository } \\
\text { corporations survey }\end{array}$ & Yes & M & M & $2-3 M$ & $1 M$ \\
\hline $\begin{array}{l}\text { External sector: balance of } \\
\text { payments }\end{array}$ & Yes & A & A & $6-9 M$ & $\begin{array}{l}\text { Sent to the IMF } \\
\text { within } 6 \text { M after } \\
\text { the end of the } \\
\text { reference period. }\end{array}$ \\
\hline $\begin{array}{l}\text { International investment } \\
\text { position }\end{array}$ & No & $A$ & $N A$ & $6-9 M$ & $N A$ \\
\hline \multicolumn{6}{|c|}{ DATA CATEgORIES AND INDICATORS } \\
\hline \multicolumn{6}{|l|}{ Real sector } \\
\hline GDP (nominal and real) & Yes & $\begin{array}{l}\text { A }(Q \\
\text { encouraged) }\end{array}$ & $\mathrm{A}$ & $6-9 M$ & $18 M$ \\
\hline $\begin{array}{l}\text { Gross national income, capital } \\
\text { formation, saving }\end{array}$ & Yes & A & & $6-9 M$ & \\
\hline $\begin{array}{l}\text { Manufacturing/industrial } \\
\text { production index }\end{array}$ & Yes & M & NA & $6 W$ & $N A$ \\
\hline Primary commodities & No & As relevant & NA & $\begin{array}{l}3 M \text { for all } \\
\text { indices }\end{array}$ & $N A$ \\
\hline Consumer price index & Yes & M & M & $1-2 M s$ & $\begin{array}{l}\text { Within } 5-20 \mathrm{D} \\
\text { after the end of } \\
\text { the reference } \\
\text { period. }\end{array}$ \\
\hline Producer price index & No & $M$ & $N A$ & $1-2 M$ & $N A$ \\
\hline Employment & Yes & A & NA & $6-9 M$ & $N A$ \\
\hline Unemployment & No & A & NA & $6-9 M$ & $N A$ \\
\hline Wages/earnings (all sectors) & Yes & $\mathrm{A}$ & & $6-9 M$ & $N A$ \\
\hline \multicolumn{6}{|l|}{ Fiscal sector } \\
\hline $\begin{array}{l}\text { Central government budgetary } \\
\text { aggregates }\end{array}$ & Yes & Q & $M, Q, A$ & $1 Q$ & $2 W$ \\
\hline Interest payments & No & $Q$ & & $1 Q$ & \\
\hline $\begin{array}{l}\text { Central government debt: } \\
\text { domestic and foreign debt, } \\
\text { as relevant, with appropriate } \\
\text { breakdowns (debt holder, } \\
\text { instrument, currency) }\end{array}$ & Yes & $\begin{array}{l}\text { A }(Q \\
\text { encouraged })\end{array}$ & & $1-2 Q$ & \\
\hline
\end{tabular}




\section{Rwanda: Overview of Current Practices Regarding Coverage, Periodicity, and Timeliness of Data Compared with the GDDS}

\begin{tabular}{|c|c|c|c|c|c|}
\hline & $\begin{array}{l}\text { Availability } \\
\text { of the Data }\end{array}$ & $\begin{array}{c}\text { GDDS } \\
\text { Periodicity }\end{array}$ & $\begin{array}{c}\text { Rwanda } \\
\text { Periodicity }\end{array}$ & $\begin{array}{c}\text { GDDS } \\
\text { Timeliness }\end{array}$ & $\begin{array}{c}\text { Rwanda } \\
\text { Timeliness }\end{array}$ \\
\hline Government-guaranteed debt & Yes & $A$ & & $1-2 Q$ & \\
\hline \multicolumn{6}{|l|}{ Financial sector } \\
\hline $\begin{array}{l}\text { Broad money and credit } \\
\text { aggregates: net external } \\
\text { position, domestic credit, } \\
\text { broad or narrow money }\end{array}$ & Yes & $M$ & $M$ & $2-3 M$ & $1 \mathrm{~W}$ \\
\hline $\begin{array}{l}\text { Central bank aggregates: } \\
\text { monetary base }\end{array}$ & Yes & $M$ & $M$ & $1-2 M$ & $1 \mathrm{~W}$ \\
\hline \multirow[t]{2}{*}{$\begin{array}{l}\text { Short- and long-term govt. } \\
\text { security rates, policy } \\
\text { variable rate }\end{array}$} & Yes & $M$ & $M$ & $\begin{array}{l}\text { In high- } \\
\text { frequency } \\
\text { publication }\end{array}$ & $\begin{array}{l}\text { The repo rate is } \\
\text { disseminated on } \\
\text { the first business } \\
\text { day after the end } \\
\text { of the reference } \\
\text { month. }\end{array}$ \\
\hline & & & & & $\begin{array}{l}\text { The money } \\
\text { market rates are } \\
\text { published on the } \\
\text { NBR's website on } \\
\text { the same day that } \\
\text { operations are } \\
\text { concluded and } \\
\text { are reported to } \\
\text { subscribers when } \\
\text { the auction } \\
\text { results are } \\
\text { published. }\end{array}$ \\
\hline $\begin{array}{l}\text { Money or interbank market } \\
\text { rates and a range of deposit } \\
\text { and lending rates }\end{array}$ & Yes & $M$ & & $\begin{array}{l}\text { In high- } \\
\text { frequency } \\
\text { publication }\end{array}$ & \\
\hline Share price index, as relevant & $N A$ & $M$ & $N A$ & $\begin{array}{l}\text { In high- } \\
\text { frequency } \\
\text { publication }\end{array}$ & $N A$ \\
\hline \multicolumn{6}{|l|}{ External sector } \\
\hline $\begin{array}{l}\text { Balance of payments } \\
\text { aggregates }\end{array}$ & Yes & $A(Q)$ & A & $6 M$ & $6 M$ \\
\hline $\begin{array}{l}\text { Public and publicly } \\
\text { guaranteed external debt } \\
\text { broken down by maturity }\end{array}$ & Yes & $Q$ & $M$ & $1-2 Q$ & $1 Q$ \\
\hline $\begin{array}{l}\text { Gross official reserves in } \\
\text { U.S. dollars }\end{array}$ & Yes & M & $D, W, M, Q$ & $1-4 W$ & $\begin{array}{l}1 \text { M after the end } \\
\text { of the reference } \\
\text { period. }\end{array}$ \\
\hline Reserve-related liabilities & No & $M$ & & $1-4 \mathrm{~W}$ & \\
\hline $\begin{array}{l}\text { Total exports and total } \\
\text { imports }\end{array}$ & Yes & M & $Q, A$ & $8 W-3 M$ & $2 M$ \\
\hline $\begin{array}{l}\text { Major commodity breakdowns } \\
\text { with longer time lapse }\end{array}$ & $N A$ & $M$ & & $8 W-3 M$ & \\
\hline
\end{tabular}




\section{Rwanda: Overview of Current Practices Regarding Coverage, Periodicity, and Timeliness of Data Compared with the GDDS}

\begin{tabular}{|c|c|c|c|c|c|}
\hline & $\begin{array}{l}\text { Availability } \\
\text { of the Data }\end{array}$ & $\begin{array}{c}\text { GDDS } \\
\text { Periodicity }\end{array}$ & $\begin{array}{c}\text { Rwanda } \\
\text { Periodicity }\end{array}$ & $\begin{array}{c}\text { GDDS } \\
\text { Timeliness }\end{array}$ & $\begin{array}{c}\text { Rwanda } \\
\text { Timeliness }\end{array}$ \\
\hline Exchange rates: spot rates & Yes & $\mathrm{D}$ & $\mathrm{D}$ & $\begin{array}{l}\text { In high- } \\
\text { frequency } \\
\text { publication }\end{array}$ & Almost no delay \\
\hline Population & No & $\begin{array}{l}\text { Annual Census } \\
\text { every ten years }\end{array}$ & NA & $\begin{array}{l}\text { 3-6 Mfor } \\
\text { annual } \\
\text { updates; } \\
\text { 9-12 Mfor } \\
\text { census }\end{array}$ & NA \\
\hline $\begin{array}{l}\text { Disaggregated population } \\
\text { data, demographic } \\
\text { indicators. }\end{array}$ & No & $\begin{array}{l}\text { Annual Census } \\
\text { every ten years }\end{array}$ & & $\begin{array}{l}\text { 3-6 Mfor } \\
\text { annual } \\
\text { updates; } \\
\text { 9-12 Mfor } \\
\text { census }\end{array}$ & \\
\hline Health & No & $\begin{array}{l}\text { A } \\
\text { (outbreaks of } \\
\text { contagious } \\
\text { diseases } \\
\text { should be } \\
\text { reported at } \\
\text { higher } \\
\text { frequency and } \\
\text { with greater } \\
\text { timeliness) }\end{array}$ & NA & $3-6 M$ & NA \\
\hline $\begin{array}{l}\text { Disaggregated resources } \\
\text { data, service delivery } \\
\text { measure, overall burden of } \\
\text { disease. }\end{array}$ & No & $\mathrm{A}$ & NA & $3-6 M$ & NA \\
\hline Education & Yes & A & NA & $\begin{array}{l}6-12 M \\
\text { following } \\
\text { beginning of } \\
\text { school year }\end{array}$ & NA \\
\hline $\begin{array}{l}\text { Disaggregated resources } \\
\text { data, enrollment rates, } \\
\text { standardized achievement } \\
\text { scores. }\end{array}$ & No & A & & $\begin{array}{l}6-12 \mathrm{M} \\
\text { following } \\
\text { beginning of } \\
\text { school year }\end{array}$ & \\
\hline Poverty & No & 3 to $5 \mathrm{Y}$ & NA & $\begin{array}{l}6-12 \mathrm{M} \\
\text { following } \\
\text { survey }\end{array}$ & NA \\
\hline $\begin{array}{l}\text { Income/consumption by } \\
\text { household or per capita, } \\
\text { data disaggregated by area. }\end{array}$ & & 3 to $5 Y$ & & $\begin{array}{l}6-12 \mathrm{M} \\
\text { following } \\
\text { survey }\end{array}$ & \\
\hline
\end{tabular}

Source: Draft GDDS metadata-Italics indicate encouraged categories.

Note: $\mathrm{A}=$ annual; $\mathrm{D}=$ daily; $\mathrm{M}=$ monthly; $\mathrm{Q}=$ quarterly; $\mathrm{W}=$ weekly; and $\mathrm{Y}=$ years; $\mathrm{NA}=$ not applicable. 